RRN M F N euromuscular J ournal

27 Crossroads

A full-length play

By Walter Anderson

wal tersound@mac. com

WGA West \#2050275

U.S. Copyright 
RRN M F N euromuscular J ournal

ii.

"They say that kid Robert Johnson disappeared for quite a spell. When he came back, he could play the guitar better than anybody else. They say he made a deal with the Devil down at the Crossroads. When you make that deal, you might not make it past 27"

-Anonymous Bluesman 


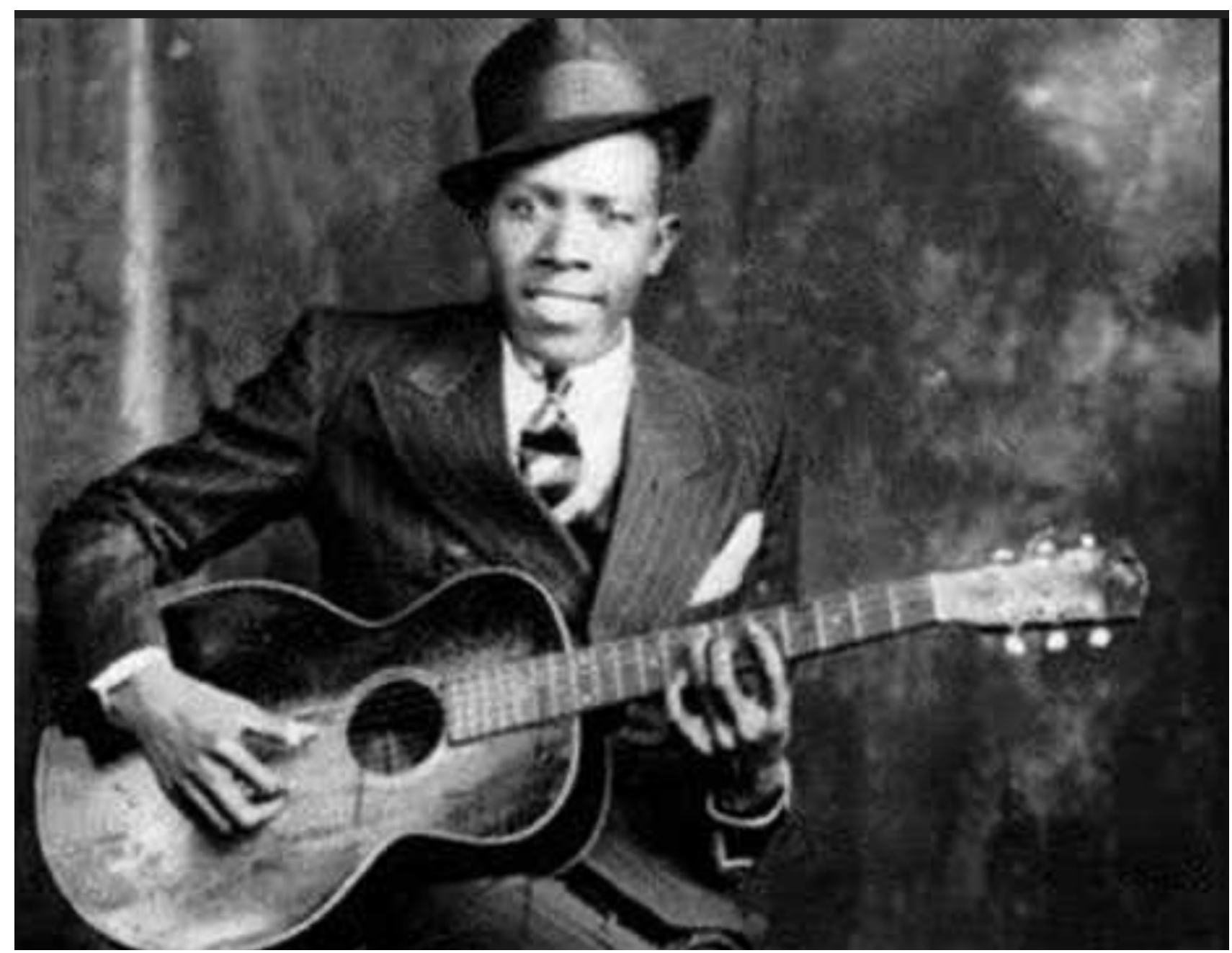


RRN M F N euromuscular J ournal

iv. 


\section{ACT I}

SCENE 1

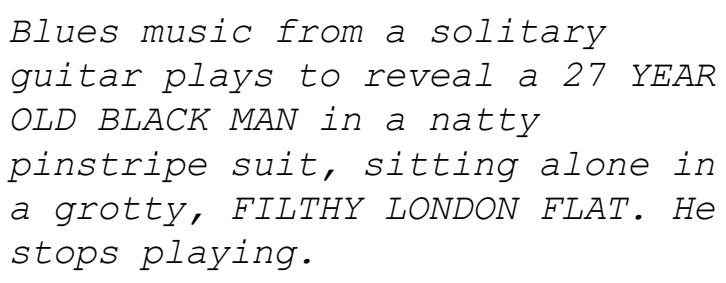

MAN

Good Evening Ladies and Gentlemen, and welcome to the show. If you like the Blues, you came to the right place. If not, there's still time to ask for a refund at the front door. Good luck with that. In the cotton fields where I'm from, there's a nearby Indian tribe that believes that when you say a dead person's name, you bring them back to life. Perhaps only briefly. But, when you play their music, strum it just so, well, that's a whole 'nother thing altogether... You're gonna hear some music here, but mostly there'll be a bunch of skinny white kids talkin" bout it. Four of them are my "flat mates" as they say around here, and they are a lazy lot. Allow me to introduce these no good Nankers, they'll all be here pretty soon-

(Sound cue- WW2 WARNING SIREN blares)

SCENE 2

The SOUND of WW2 bombers as they drop a load overwhelm and SHAKE a DARTFORD HOSPITAL NURSERY WARD. THREE NURSES are nOn plussed as they tend to HALF DOZEN BABIES.

HEAD NURSE

Caught in the crossfire for the third time this shift! Mr. Churchill is not making Britain Great again as promised, I'm afraid. 
HEAD NURSE

Funny Ears here refuses to take a drop. He's the skinniest one here-

(a nearby baby starts a CRYING FIT

and all three nurses react)

HEAD NURSE

He just won't shut up, that one, will he? That baby with the big lips is the loudest one I've ever heard, I swear!

(all three drop what they're doing to fuss over him)

SCENE 3

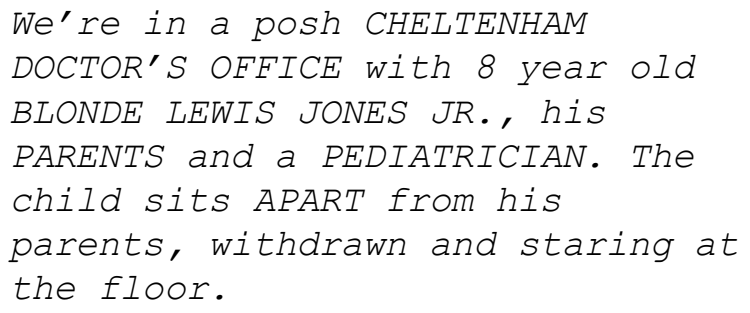

(The parents are somewhat staggered)

DOCTOR

It's a lifelong condition, but yet very manageable with the right therapies.

LEWIS JONES SR. (Resigned acceptance)

Well, it won't keep him out of Oxford. Or even Cambridge. Perhaps this will help keep him less... distracted.

$$
\text { (Lewis Jr. remains withdrawn) }
$$

LOUISA JONES

What therapies should we be doing? Which are the best? Cost is not an issue; we have a telephone and a motorcar- 
DOCTOR

I will give you an inhaler which will quell these short fits. Long term, we would strongly endorse a musical instrument to strengthen his lungs. A clarinet often works well-

LOUISA JONES

Well, my side of the family is very musically talented.

LEWIS JONES SR.

And most of them are on the dole. Music didn't get the doctor this nice office, did it?

DOCTOR

You work at over the Cheltenham Aeronautical Research Institute I understand, Mr. Jones?

LEWIS JONES SR. Actually yes, I'm head of the Airworthiness Department. Jet engines. Hurricanes, Spitfires and the like.

DOCTOR

Wow. Impressive.

LEWIS JONES SR.

Well, first in flight, we like to say.

(Sound cue- a lone woodwind instrument)

SCENE 4

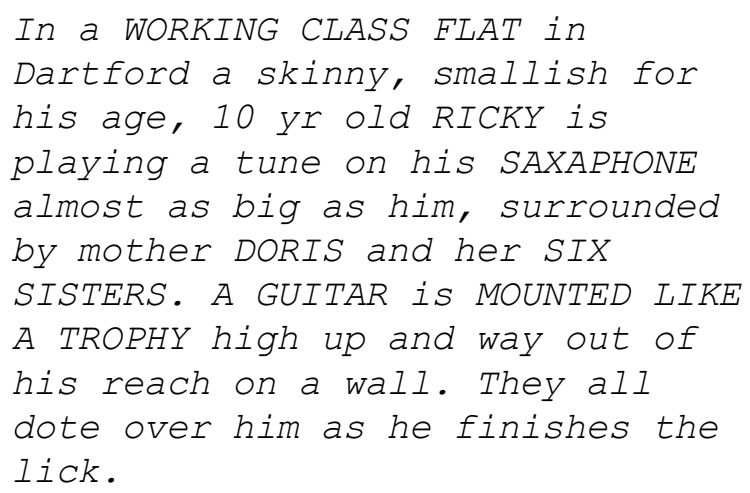

(his aunts clap and cheer,) 
AUNT \# 1

That was SO wonderful! Yet another Dupree to the center stage!

DORIS

Ha! You don't know the half of it! Should I tell them?

RICKY

(protesting)

No Mum, please...

(excitement mounts)

OTHERS

What?? TELL US!

DORIS

Well, he's been one of three boys selected for choir at a special service at Westminster Abbey...

(the room quiets)

DORIS

My son singing to a Royal Audience, the Queen herself!

(The room erupts and Ricky gets smothered by the women. Doris goes offstage briefly, reappearing with the ridiculous effeminate FLUFFY COSTUME Ricky is to wear. He puts up a weak fight as they dress him like a Barbie doll.)

AUNT \#2

Do you think his grandpa will let him, you know, on the account of this?

(the commotion halts; all eyes go

to the GUITAR MOUNTED ON THE WALL)

DORIS

Well, Dad is pretty firm about him mastering at least three instruments before that thing comes down off the wall. But if this singing goes well...

(cue Skiffle song) 
SCENE 5

A few blocks away in an UPGRADED

FLAT a same aged, but much taller

MIKE performs karaoke style to

this tune with a hairbrush

microphone from a spinning 45.

His mum EVA sits with younger

brother CHRIS in her lap. Across

the room his $P E$ teacher father

JOE dressed in track suit and

WHISTLE around neck, views the

spectacle disapprovingly with

crossed arms. This kid's moves

are pretty good for someone his

age. The song ends, Mum puts down

Chris to hug Mike-

EVA

(ecstatically)

Smashing! Where in ever did you get such natural rhythm I'll never know!

MIKE

Well you ain't seen nothing yet, ladies and gentlemen-

(He motions to little Chris to

change the record, who puts on a

LITTLE RICHARD song, Mike jumps and

spins. Joe BLOWS THE WHISTLE and

halts everything. Needle off the

record-

JOE

(yelling)

That's it! This is finished- there will be NO jungle music in this household, as long as I'm here! This does not qualify as fitness on any level, young man! Give me thirty press ups, right now!

(A wet blanket on the party, Mike

drops to the floor and dutifully

complies.) 
SCENE 6

Cheltenham Grammar

School, stately and traditional. Louise and Lewis Sr. have been summoned to HEADMASTER STERN'S

OFFICE. They sit opposite his desk, on separate chairs.

HEADMASTER STERN

No, Mrs. Jones, your son has done nothing wrong. Yet. In fact, his marks are quite good, near the top in most of his courses. That is the concern, that there is this trend-

Trend? What trend?

LEWIS JONES

HEADMASTER STERN

With your son and with some others. I would use the word defiance, but perhaps that is a strong word at this point. It is 1956 after all, and we realize Britain is blazing a new path into the future. Certainly no one is more aware of this than you, Mr. Jones. Those new Rolls Royce jet engines of yours are the stuff of space.

LEWIS JONES SR.

Thank you, but I cannot discuss a classified topic any further, obviously...

HEADMASTER STERN

At your factory there is of course a system in place. There is a structure of levels. Of order. Our society relies on it, too. We must be better prepared for that next war. This is Cheltenham Grammar, not a Tech School. At prestigious institutions like this one, it is imperative that along with providing a basic starting point for all the noble disciplines, we also send our students on with a sense of Order. They will lead our future. Our cousins across the pond have a completely different way of doing things. More experimental. Less order. We'll see how that works. Some of their music that has snaked it's way over here is encouraging of bad behavior-

LOUISA JONES

(interrupting)

Pardon, but what does all this have to do with our boy? 
HEADMASTER STERN

Part of our responsibility here, Mrs. Jones, is to monitor the social well being of all our students. Your son has had his slips here and there, not entirely unusual. His asthma problem has caused him to drop out of varsity sports, which is a school point of pride, but, he has channeled his talents into many musical instruments and mastered them. Including the guitar. In fact, apparently young Mr. Jones has been playing at times in a rather unsavory jazz and blues place across town. During school hours. I don't know if you were aware-

$$
\text { LOUISA JONES }
$$

Blue Place?

HEADMASTER STERN

He's had several absences attributed to doctor's appointments, are you aware of those as well?

(the parents exchange a look, Stern opens a folder)

HEADMASTER STERN

Here's a recent comment from one of his councilors: "Lewis Jones Jr. is clever, but needs careful handling. There is a reckless potential there." Then there is this. From our girl's school. It has been noted that one of the students has taken a leave of absence. There is a disturbing account that one of our students has gotten one of theirs into "trouble." Your son's name has come up.

(The Jones are stunned)

SCENE 7

Tech Schoolboy Ricky comes running round the corner into a DARTFORD BACK ALLEY, books on his back. He stops, out of breath. VOICES offstage yell back and forth. Ricky eyes a LARGE ASHCAN and hides behind it. A BULLY student comes from the direction Ricky did, a BIGGER BULLY emerges from the other end of the alley. 
BULLY \#1

Okay sister boy, you are a trapped rat now. You'd best come out, or we give you twice the usual!

(they continue searching)

BULLY\#2

We can smell your perfume, the same crap you slathered on for the Queen...

(Ricky emerges from hiding, with a

black eye from a previous beating)

\section{RICKY}

(digging into pockets)

Here's 2p, it's all I have.

(Bully \#1 snatches the coin and SLAMS Ricky into the ashcans violently. He slowly rises back up. )

\section{BULLY \#1}

It would be a lot easier on all of us if you would simply present this to us earlier in the day, Monkey Ears. A time saver.

(He gut punches Ricky, who doubles over on the ground.)

\section{BULLY\#2}

Aw, you should show a little more compassion, mate! Our classmate here has been demoted from Choir, on account his lovely girlish voice has cracked in puberty. Cruel, such a shame. Imagine, all that practice and field trips to London down the drain! Insult AND injury indeed. And speaking of demotion, all that time away has caused all the Choir Trophy boys to stay back a year!

(The bullies share a big laugh. Ricky curls into a big hedgehog ball. The bullies are about to leave.) 


\section{BULLY \#1 \\ (sniffing in Rich's \\ direction)}

All this heavy breathing has revealed a familiar scent. Black Courant Chewies. My fave!

(Ricky quickly removes a candy box from his bag and tosses before they do further damage, curling quickly back up. A Bully grabs his book bag and dumps the remaining contents on ground, then tosses the bag.)

\section{BULLY\#2}

On top of everything else, he has an "honesty" problem as well. A total disaster.

(He shakes his head and gives Ricky a swift hard kick in the arse. Ricky yells. The bullies chuckle and exit. Staying curled up until he's sure they're gone, he gets up, gathers his things, and heads off.)

SCENE 8

Inside Ricky's family flat, Grandpa Gus and mum Doris await his return from school. Gus is stringing a VIOLIN and sipping his TEA.

GRANDPA GUS

I don't know Doris, I don't have a lot experience with adolescent boys. I had seven daughters for chrissakes. Eight, counting your mum. What does Bert have to say in all this?

DORIS

(upset)

Bert is always at work. Even when he's here, which is late every damn night, he's on about the factory. Then on weekend, he's off to the tennis club. He takes him along, and then makes him chase all the errant balls the whole day. He almost got electrocuted on the rail tracks last Saturday. 
On top of getting sacked from choir the day before. And now it's likely he'll have to repeat a year!

(Doris is about to breakdown, but pulls it together as she HEARS

RICKY at the front door.)

DORIS

Hey there, handsome! How was your day? Your Grandpa came-

(A beaten Ricky blows through the

lounge straight out the back

without acknowledging anyone. He

SLAMS the backdoor.)

DORIS

Crap. He's gotten his arse kicked, again. He's such a wuss. I've had it with those hooligans, I'll get with their mums. Now he's off to his tent for the rest of the day.

The tent I got for him?

GRANDPA GUS

(Behind the actors, (who are oblivious to this), the mounted GUITAR STARTS TO SPIN, SlOwly at first.)

DORIS

(sarcastically)

Yes, thanks by the way. He's pitched it out back, and just retreats back to it for hours upon end, doing God knows what in there. He's taken a turn for the dark, that one, I tell you.

(a few beats)

DORIS

(losing it)

You go talk to him!

(THE GUITAR STOPS ABRUPTLY. She exits. Gus's gaze follows her out, then his attention shifts to the mounted guitar, curiously. He notices it is now OFF TILT. 




SCENE 9

The backyard of the flat is in the ugly part of Dartford town, still pockmarked with the LEFTOVER WAR RUBBLE. A smallish RED TENT is pitched amongst the STACKS of rotten TOMATO CRATES from the green grocer shop on the bottom floor of the flat. Gus looks at the tent, which GLOWS from light inside. He starts to play an OLD BLUES TUNE. Ricky emerges slowly from the tent, like a charmed snake.

GRANDPA GUS

(finishing the riff)

I came over to re thread the violin, but I can see this needs some tending to-

\section{RICKY}

I thought it was not to be touched-

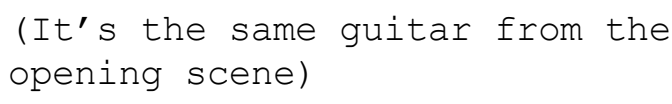

\section{(Rich just stares at it.)}

GRANDPA GUS

I know I've been keeping it from you. Waiting for the right time. You've gotten decent on all the others, so, I think the time has come for this. 
I will caution you, the problem with this damn thing is once you pick it up, all the others won't interest you so much. You'll ignore them. That I know first hand.

(He hands the guitar over to Ricky, who runs his hands over the curves like a teenage boy discovering the opposite sex for the first time.)

GRANDPA GUS

...Okay, there are three basic chords, learn them and you can build ten thousand songs, just like those Cambridge science guys showed us you can make a dinosaur or a beetle from just four proteins...

(The kid has the guitar now as the lesson commences.)

MUSIC CUE

SCENE 10

A KITCHEN at an American Air Force base near Dartford. JOSE, a two striper enlisted black man is washing up and singing along to a record amongst STACKS OF UNWASHED DISHES. JOE and MIKE enter.

JOE

Jose, turn that noise off! Please- you know that's not allowed!

JOSE

(shutting off music)

I'm so sorry sir. I completely forgot, sir, my mistake.

JOE

I'm doing a rock climbing seminar over at the gymnasium, the $\mathrm{BBC}$ is here to see it. If they like it, they're going to put it on the telly.

JOSE

(impressed)

No kidding, television? 
JOE

Yes! And Mike here could very well be one of the youth demonstrators.

JOSE

Mike?

(Mike nods enthusiastically.)

JOSE

A television star right here In my kitchen, my lord.

$\mathrm{JOE}$

Well I'm off, I'll be back round half six. Put him to work, Jose.

(Joe EXITS)

JOSE

Ok, rock climbing star, you know the drill. Wash three stacks, get a cheeseburger.

(Mike rushes over to the grill. Jose playfully stops him.)

After, not before.

JOSE

(Mike dons some RUBBER GLOVES and

dives in. The LIGHTS DIM TO BLACK

for a few moments, and then FADES

UP with MUSIC PLAYING as we rejoin the scene in the NOW TIDY KITCHEN. (the scene resumes with JOSE PLAYED BY THE ACTOR FROM SCENE 1.) Jose is dancing to a record, there are SEVERAL RARE BLUES RECORDS spread out on the table. Mike is in heaven, eating the CHEESEBURGER, studying JOSE'S MOVES and simultaneously drooling over the album covers. The SONG ENDS.)

MIKE

Fantastic! Who was that? 
JOSE

That there is Howlin' Wolf.

He grabs the album cover and hands

it to Mike.

MIKE

Such a cool name. Where did you get all these?

JOSE

Brought some over. Sent home for most of em. Chess Records in Chicago.

(Picks up an album, points to the back corner.)

JOSE

The address is right here.

$$
\text { (Hands to Mike.) }
$$

JOSE

Tell you what. I loan you a few, you wear the shit out of em, learn em, then bring em back next time. I'll give you a few more. Kinda like a library.

MIKE

Oh my god, are you kidding? My Pops-

JOSE

Don't you worry bout that. I got you covered.

(Jose looks over to the door

perceptively, then scoops up all

the music and disappears into the

background, just as JOE ENTERS.)

JOE

(Triumphantly)

Ha Ha Ha, sealed the deal! And you my son, are set to be the main Youth Demonstrator for the entire telecast! To be seen in Scotland, Wales and Ireland as well!

(Mike is excited too, and Jose re enters with a neat BUNDLE under his arm.) 
JOSE

Man, that is something else, sir. And to think, I got to witness the whole thing, right here. Well done, sir.

JOE

Thank you so much, Jose, for minding Mike. C'mon Mike, we've got a lot to do

$$
\text { (Heading to the door) }
$$

JOSE

Oh Mike, here's that stuff-

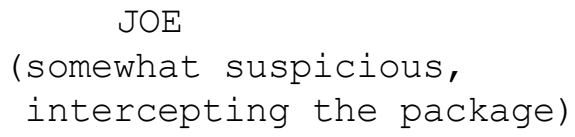

What's all this?

JOSE

Some old uniforms I was gonna toss out. Mike said he wanted them.

(Jose extends hand to Mike, they SHAKE . )

JOSE

Thanks Mike, you're more help than you know. You have a great kid here, sir.

JOE

So kind of you Jose. Those kids will wear anything, I suppose. Thank you, Jose.

$$
\text { JOSE }
$$

My pleasure Mr. Jagger. My pleasure indeed.

The same alley where Ricky got his ass kicked. He's a little bigger now, and more confident. He goes by a different name from now on. The bullies have him cornered. 
RICKY (NOW KEITH)

Hey fellas, I was looking for you-

BULLY \#1

No kidding, imagine your luck. Give over Monkey Boy.

$\mathrm{KEITH}$

I've been meaning to introduce you to my new mate Nigel.

(ENTER NIGEL, a MASSIVE

upperclassmen Rugby player. He's got a RUGBY BALL under his arm. The bullies freeze in their tracks.)

$\mathrm{KEITH}$

Nigel here has a bit of a fancy for my cousin Kate, and we're on the way over to her house for an introduction and the like. He's first team second row on our varsity, and they happen to be recruiting for fall. I have been telling, kind of bragging, actually, about your boys' ...athleticism.

\section{BULLY \# 1}

...Well, I'm not into sport so much.

The other bully shakes his head.

NIGEL

It's really quite basic, mates. Let me demonstrate.

(The prospective players start to back off.)

BULLY\#2

That won't be necessary. We're not interested.

NIGEL

Here, you're on the attacking side-

(He tosses ball to Bully \#2, who catches it but stands limply.)

NIGEL

Now, Keith and I are defenders. The basic tackle:

(He smashes the bully to the ground with a BONE CRUSHING TACKLE. 
The other one bolts, but not before Keith can BOOT HIM IN THE ASS. The former bully writhes on the ground.)

KEITH

I'm sorry Nige, I guess I was wrong. Maybe they don't have the makeup after all.

NIGEL

Well, if you lads change your minds, I'll have eyes on you. (The ruggers exit.)

\section{END ACT I}




\section{$\underline{\text { ACT II }}$}

SCENE 1

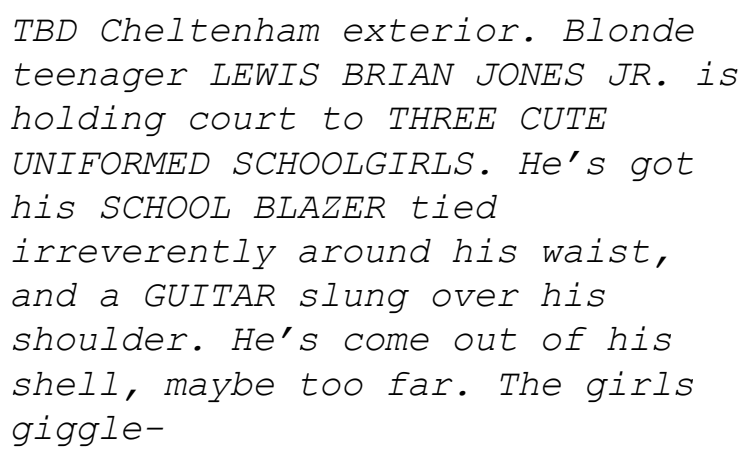

What do you say we get out of these silly prison rags and head over to the clubhouse? I've got a new tune to show off.

\section{SCHOOLGIRL \# 1 \\ (Teasing)}

Tune, or show off a new outfit? You are such the peacock Jones.

\section{BRIAN}

I do detest uniforms of any kind. It's like you're in the army. When you're not even.

\section{SCHOOLGIRL \#2}

Well if you get in that band you talk about, they'll make you wear one. And the same haircut.

$$
\text { BRIAN }
$$

Bollocks they will. I'd quit them straight away.

$$
\text { SCHOOLGIRL \#2 }
$$

Such the rebel. So James Dean. But only blonde!

$$
\text { (She musses his hair) }
$$

BRIAN

No really, it's like they're preparing us all to work in some giant sooty gray factory in Leceister. 
(mimicking factory workers)

\section{BRIAN}

"Hey Earnie, here's another bolt. Cheers mate, I'll give it to Earnie Number Two, he'll put a nut on it. Then let's do it like six hundred and sixty-six more times. We'll have us a pint at the pub across the way with all the other Earnies after the end whistle." ...If you stay at it for twenty years grinding away, they'll promote you to Supervisor Earnie... To all that, I politely say, no thank-you.

\section{(The girls giggle at his funny} voices)

BRIAN

What is it you lovely ladies see yourselves doing after all this?

SCHOOLGIRL \#2

Easy. I love horses, so probably I'll be a veterinarian or the like.

\section{SCHOOLGIRL \# 1}

I'm already set up to have a chair in my aunt's hair salon. I simply can't get there soon enough. I love everything about styling.

BRIAN

Really?, And what would you do with mine?

$$
\text { (she touches his hair) }
$$

SCHOOLGIRL \# 1

First you grow it long, like those Liverpool boys, then you fluff it all up, by frequent shampooing... What kind of music is your band going to play?

\section{BRIAN}

The Delta Blues for sure. Muddy Waters, Elmore James, Leadbelly, Howlin' Wolf. Robert Johnson, they all copied him. He died at age 27. They say he made a deal with the Devil so he could play better than anyone else.

$$
\text { SCHOOLGIRL \#2 }
$$

Wonderfully colorful names. Would you make that same deal if you could? 
(He swings his guitar around, runs

his fingers over the strings for

effect, and waits a beat.)

BRIAN

...In a Mississippi minute ma' am, in a Mississippi minute...

(They laugh at his attempt at a southern accent)

SCHOOLGIRL \#2

With what name?, You'd have to get a better stage name!

BRIAN

You have a point. Lewis Brian Jones Jr. Sounds much too nice. And too English. I'd change it up a bit. "Elmo Lewis" has a ring to it...

(The girls give their approval. His attention shifts to Girl \#3, who has remained quiet so far. She's far the fairest, and he likes the cut of her jib.)

BRIAN

And you Diane, what is your dream job?

SCHOOLGIRL \#3

It's Denise, first of all. Secondly, it's not really a job I'm after, I'll just continue modeling, until I meet that fabulously rich entertainer and we move to the Antilles and make babies...

BRIAN

Sounds to me the best plan of all.

\section{SCHOOLGIRL \# 1}

Speaking of babies, did you hear about that girl who got preggers over at Brian's sister school? Put it up for adoption, she did-

(The conversation tacks in the opposite direction, and he slows his roll.) 
SCHOOLGIRL \#2

They just can't keep their knickers on over there, can they? Which classmate is it?

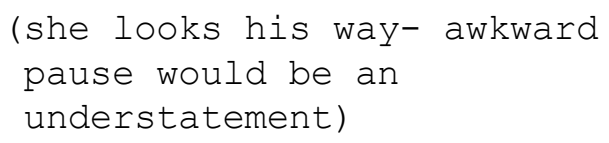

\section{SCHOOLGIRL \# 1}

Well, whoever is responsible for it ought to do the decent thing and fess up. Probably one of those Rugby playersthey're always putting their hands all over everything... (Changing subject)

OK, we're off girls, let's drop by my aunt's on the way back, she's got this fab new curling iron...

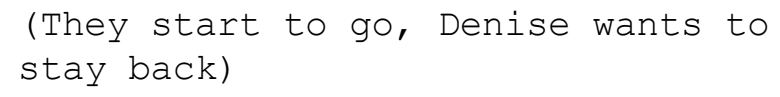

DENISE

I've got to head over to High street way to pick up some things at the Post Office-go ahead without me.

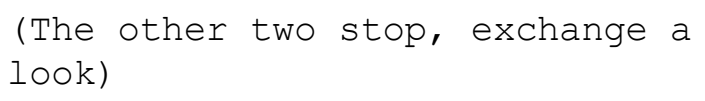

(As they EXIT) 
SCENE 2

Waikiki Clubhouse, a Cheltenham makeshift repurposed space for small music and pub food. ALEX KORNER and her JAZZ/BLUES BAND have just finished a set. The audience is clearing out as elder U.S. BLUESMAN BROWNIE MCGEE meticulously wraps his gear. Brian has been sitting in on guitar.

ALEX KORNER

Thanks for sitting in short notice, Brian. Spot on, as usual. Your dedication is really paying off. Brian, this is Brownie-

BRIAN

(Awe not worn off yet)

Yes I know. Such a pleasure to meet you, Sir. Thanks for tolerating me tagging along, sir.

(Alex heads over to the bar.)

BROWNIE

They even call me Sir around here. White joints that pay you to play AND they serve you. I could get use to this shit. You ain't bad for young white boy. Just got one thing to say...

(Brian is all ears)

BROWNIE

Which way is the free food?

(Alex motions them over to a table near the bar, Brownie makes a beeline and Brian peruses. They sit. Brownie takes a big swig of his PINT GLASS)

BROWNIE

Damn that is tasty! What do you call this kind?

BRIAN

It's a bitter. 
BROWNIE

On account of I'll be bitter if they don't pour me another one!

(He nods approval to the barkeep)

BROWNIE

We usually take it colder, but it got more flavor like this. How long you been knowin' Miss Korner, boy?

\section{ALEX}

Brian hasn't missed a show since we've started coming through here. He's a rising talent, that one.

BROWNIE

Here's your first test kid, order me something off this.

$$
\text { (hands menu to Brian) }
$$

BROWNIE

My eyes wearin' out, can't read shit no more. I been told English food is shitty and the beer is warm. This beer ain't cold; But it is cool. What $y^{\prime}$ all got close to ribs?

\section{BRIAN}

Try the steak and kidney pie, they do a good one.

BROWNIE

A pie made with a kidney. Damn. Get me some fries with that. "Chips", right?. I know 'bout that. Say, which way is the head in here? I gotta wash up.

\section{ALEX}

The 100 is that way, Brownie-

$$
\text { (She motions, he goes off) }
$$

BRIAN

Well, I guess he's not too interested in my playing.

$$
\text { ALEX }
$$

That old guy is interested in two things, his guitar and food.

(The barkeep drops off the extra beer) 
ALEX

Okay, three things...I've got some great news, Brian, but first I want to hear about you. How'd the testing go? What's up with your parents?

BRIAN

(somewhat deflated)

Not quite sure what the word "parent" actually means at this point. I think my exams were...underwhelming. Lewis has dropped the idea of me becoming the UK's foremost rocket scientist, and is now trying to push me in the direction of Optometry School. He says at the very least I can fit people with glasses...

\section{ALEX}

You should stick with your schooling, Brian.

BRIAN

I'm done with that. I'm a Bluesman now.

ALEX

There's no great future in the Blues, Brian. Not a lot of cash there. It's Elvis versus Buddy for the big money.

BRIAN

Well that's funny, coming from you... So what's the good news?

ALEX

Bobby and I have finally got the Liquor License we've been waiting forever for. We open up "Korner Jazz n' Blues" in West London next week. My Blues Incorporated group will be the house band.

BRIAN

Oh, so it's good enough for you, apparently!

\section{ALEX}

We sell booze, Brian. Music makes people thirsty.

(Brian starts to gather his things, BROWNIE'S FOOD is delivered to the table. Brownie emerges from the back, he is now PLAYED BY THE ACTOR FROM ACT I, SC I.) 
BROWNIE

Leaving so soon Mr. Jones? The fun starts when the show ends.

BRIAN

I have another gig to be at, sir. It was nice playing with you.

(Brownie extends his hand. They

SHAKE hands.)

BROWNIE

Stay the course, Brian, you've got the touch.

(Brian EXITS.)

SCENE 3

The Jagger Duplex now in a nicer part of Dartford. Upgrade. Eva Jagger is in the lounge area, drumming her fingers and sitting across from the FRONT DOOR in anticipation. Joe is dressed in a flashy track suit, gathering up ATHLETIC EQUIPMENT for work.

JOE

For god sakes Eva, go do something else, like in the garden. When the mail comes, it comes. You're not going to speed it up-

EVA

He's thirty-five minutes late. Again.

JOE

I'm telling you, the college acceptance notifications have just started to come out. It could be days. He's already got two admissions.

EVA

But not the big one. Do you know what that would mean?

(he stops what he's doing) 
JOE

The London School of Economics. Admission to The Big Boys club. That would be something for a Jagger.

EVA

Rockefeller went there. John F. Kennedy. He could do politics!

JOE

Or something useful... Anyways they'll probably just deliver a box of those stupid jungle records he squanders his money on.

EVA

It's his money, Joe. My god, that boy must have had thirty jobs by now. All favorable reviews. That looks good on an application.

JOE

Not to mention a member of nearly all the sports teams at school, in addition to all the American ones on the Base.

EVA

Along with the top marks in nearly all required categories. They'd be crazy not to take him... You know he's going by "Mick" now, all the boys in his band call him that-

JOE

Yes, "The Blue Boys" they call themselves. Well, all that will just become a weekend hobby in someone's garage when he goes off to university. The longish hair, the excessively tight pants, all those childish things will go away-

(NOISE at front door, then a KNOCK. Eva jumps up and rushes to door.)

MAILMAN

Morning Mrs. Jagger- I've got another box from Chess Records Chicago, U.S.A and 3 letters. Good day!

Thanks Cecil!

EVA

(She can't shut the door and put

down the BOX fast enough.) 


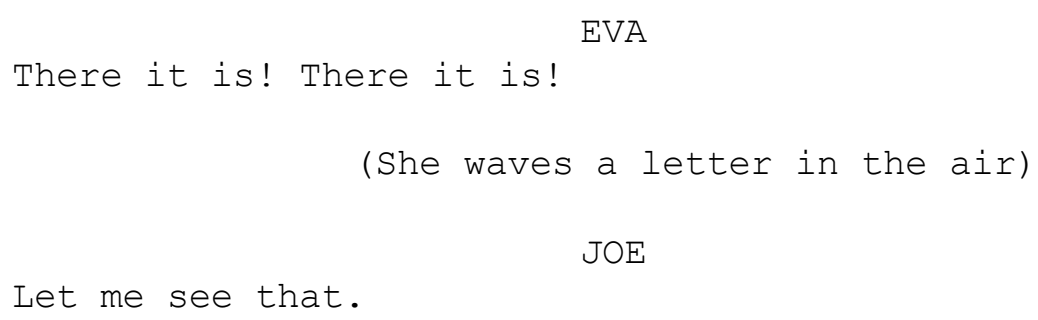

SCENE 4

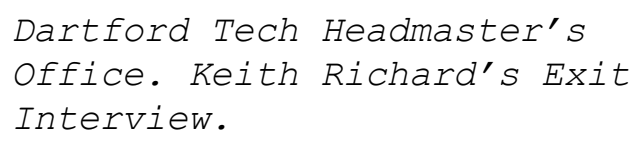


The DOOR BOLTS OPEN and HEADMASTER

CRUNGE flushes a DELINQUENT STUDENT

out.

HEADMASTER CRUNGE

That's it! We're done! If you should EVER set foot on the grounds of Dartford Tech again, the police shall be notified and you will be hauled off!

(Crunge turns to Keith, the

delinquent boy FLIPS THE BIRD at

Keith as he exits.)

HEADMASTER CRUNGE

Richards, you're next.

(The two enter the office, Crunge

is now composed.)

Please, be seated.

HEADMASTER CRUNGE

(Crunge pulls a FOLDER from a STACK

on his desk.)

HEADMASTER CRUNGE

Well, the mastermind himself. I must say, after an illustrious and decorated tenure at this school, you managed to go out with quite a bang. Cutting out with your mates on the LAST possible day and getting expelled is an act of sheer genius. Enlighten me; What was going through that pensive head of yours?

KEITH

(straightening up a bit)

Well, sir, being that as it was the last day, and that most of it was to be taken up by a meaningless assembly mostly designed for underclassmen, I, rather we, thought we'd have a smoke. Not wanting to cause any disturbance, we ventured barely off campus, apparently. Intending to return to the festivities, we unfortunately got distracted-

HEADMASTER CRUNGE

(interrupting)

Let's pause there. Smoking is prohibited in the bylaws. Leaving campus without permission is grounds for dismissal. 
Period. "Barely off campus" happens to be a pub on the High Street of the next village over.

KEITH

Well, sir, It's not exactly as it might appear. There was an element of misinformation-

HEADMASTER CRUNGE

Just stop, Richards. Expulsion from Dartford Tech has been recommended. I am in the midst of that decision, taking your record into consideration. Let's review some of your highlights:

\section{(opening folder)}

HEADMASTER CRUNGE

Seventeen absences excused by parental notes with likely unauthentic signatures. Twenty-one reports of violence or fisticuffs.

KEITH

Most of those I didn't start, I was the victim.

HEADMASTER CRUNGE

Let's move on to extracurricular activities. The Eagle Scouts.

KEITH

Learned a lot, knots and such.

HEADMASTER CRUNGE

Fantastic. Should take you far. After you rose through the ranks to Beaver Patrol, it's cited here that you instigated some whiskey drinking on an overnight which resulted in a broken bone.

KEITH

I think it was bourbon, actually.

HEADMASTER CRUNGE (slamming file down)

Our school crest is emblazoned with the image of an Oak Sapling; Not a regal symbol, but one emphasizing development a solid potential. You, Richards, are a weed. A tumbleweed at that. 
KEITH

...A weed is resilient, and a tumbleweed shows mobility. Change or die. Darwin, right?

\section{HEADMASTER CRUNGE \\ (fully lathered)}

I've spoken to your father Bert. He tells me you spend most of your time strumming a guitar and/or playing records. He seems to think the quicker you join the work force, the better. I concur. It will be my recommendation that you be declared eligible for the Labor Exchange... But someone has stepped in on your behalf, inexplicably...Mrs. Mountjoy, our Art Instructor. She seems to think you have some kind of "talent" and is willing to send Admission Approval for you to attend The Sidcup School for the Arts.

\section{(Keith perks up.)}

HEADMASTER CRUNGE

I will go on record to protest it as complete waste of education resources, but will reluctantly give you a piece of paper acknowledging the fact that you did your time here. It is NOT a diploma.

(He takes a PAPER from Keith's file folder and shoves it across the desk.)

HEADMASTER CRUNGE

Please do me the favor of not reproducing any offspring that are of age to attend this institution until I am fully in retirement. Now go away-

(Keith pops up and grabs the paper)

$\mathrm{KEITH}$

Suitable for framing. Thanks for the years of nurturing support, sir.

(Keith exits into the waiting area past the NEXT VICTIM to an ASHCAN. He stops, takes the WAD OF GUM out of his mouth, puts in the paper, forms a ball and TOSSES it into the can, and EXITS. 
SCENE 5

The Jones Residence in a bucolic cheltenham. The home has CHRISTMAS DECORATIONS. Brian and a BOOTS CHEMIST COWORKER approach the gate with their BLUE SMOCKS showing under their jackets, guitar slung over Brian's shoulder.

BRIAN

(stopping at gate)

I'm just gonna pop in, spread some holiday cheer and get a fiver off Lewis. Sure you don't want to come in for a minute?

BOOTS CO WORKER

No, I was never a favorite of his- I'll catch up with you over at Waikiki.

BRIAN

$$
\text { (to self) }
$$

You are not alone there, mate.

BOOTS CO WORKER

(exiting)

Be sure to say Happy Christmas to everyone!

(Brian OPENS GATE and heads to the front door. He stops there and notices a PILE OF BELONGINGS. There's a LETTER TAPED to the top of the pile. Brian slowly walks over, picks up an item, recognizing the things as his. Sitting on a TRUNK, he OPENS THE LETTER reads the note.)

As the LIGHTS DIM on the MAIN SET, a spotlight illuminates ONLY LEWIS JONES, SR. On a FAR SIDE OF THE STAGE. 
LEWIS JONES SR.

You are disowned. You're no longer our son. You gave up on your scholarship, you gave up your education, your career, everything else that was planned for you. Go to London to be a bum and hang out, and be with people like those derelict musicians. We're on holiday. When we return, be gone. Enclosed is a cheque for 200 pounds. Don't ever knock on our door again.

The SPOTLIGHT goes DARK as the LIGHTS ON THE MAIN STAGE FADE UP. Brian soaks up the last bit for a beat or two, and jumps to his feet.

BRIAN

(Yelling for all to hear)

HAPPY FUCKING CHRISTMAS EVERYONE!

(A LIGHT goes on NEXT DOOR.)

END ACT II 


\section{ACT III}

SCENE 1

Cheltenham Train Station. Brian's TRUNK AND BAGS lean up against CLASSIC RED PHONE BOOTH as he feeds coins.

BRIAN

I'd like the number for a Robert or Alexis Korner in West London please, that's Korner with a K... Yes, Ealing would be it. Thank you so much, Happy New Year to you too, cheers.

$$
\text { (He hangs up, dials) }
$$

BRIAN

Hello, Bobby? This is Brian Jones. Yes, the blonde one. Happy New Year!...Great to hear your voice, been a bit...Yes, everything's great. Is Alex there? Just wanted to wish herSure, I can wait... She's not. OK. So how's the new Club getting on?...Fantastic! Say, chance has me in the area today, how about I come by and check it out? She'll be at the club later? What's the address again? I think I've lost it... Magic, will I see you there?... Great, cheers Bobby.

(He writes on his hand)

BRIAN

I'm super close by. Great- I'll stop by, and I'll bring my gitty, see you soon.

(He hangs up, quickly gathers his belongings and hustles over to the TRACKS . ) 
SCENE 2

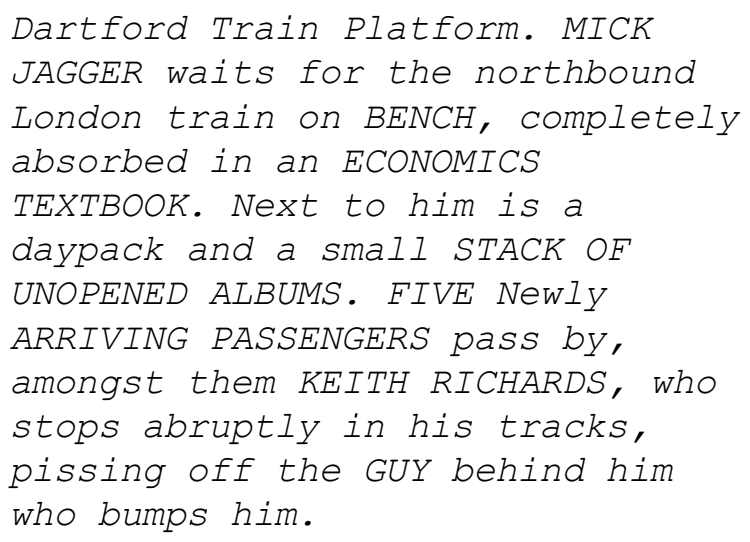

KEITH

Mike. Mike Jagger.

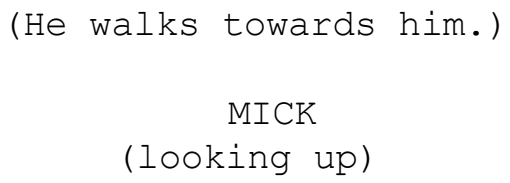

Yeah what?

KEITH

It's Keith. Keith Richards from Primary school.

MICK

(feigning recognition)

Oh, hey Keith, great to see you.

KEITH

Is that your chuck Berry record? I have the same one. That's the only other one I've ever seen. Can I have a look?

MICK

(slightly annoyed)

Yeah, I guess. Okay.

$$
\text { (hands to Keith) }
$$

KEITH

(examining)

It's brand new, never been played. It's beautiful. Mine's scratched to shit and doesn't have a back. Damn. Well, you'll absolutely fall in love with it. 
(He hands it back, starts to leave)

MICK

Do you play?

KEITH

Yes, quite a bit, in fact.

MICK

What kind of stuff?

$\mathrm{KEITH}$

That kind of stuff. I can play every track on that album, top to bottom. It's pretty basic, really.

MICK

(now interested)

Do you have a minute? Here, have a seat...

(He moves his pack)

KEITH

(sitting)

You heading north?

MICK

Yeah. LSE, First year. This shit is really dense, but I seem to be hanging in there.

(puts book away)

KEITH

I'm just back from sidcup.

\section{MICK}

The Art school? How do like it? Must be lots of tail running around down there-

\section{KEITH}

Not as much as you'd think. The School? There's more talking about art than actually doing it... Say Mike, Do you think I could have a look at the rest of those records?

MICK

(glancing at watch)

Looks like my train is late. Yeah, sure. 
(He hands the stack over. Keith cant't believe his eyes.)

KEITH

Holy shit! Wow. I didn't know these even existed! Where did you get these?

MICK

Chicago. Chess Records. Sent away two months ago. Just arrived, haven't had the time to spin them yet.

As the boys have been talking, a black man in the uniform of a BRITISH RAIL OFFICIAL has approached a giant INFORMATION BOARD in the BACKGROUND. Next to a panel that reads 14:27 KINGS CROSS, LONDON he slides in a panel that reads CANCELLED in BIG RED LETTERS. A VOICE comes over a PA SPEAKER.

PA SPEAKER

MAY I HAVE YOUR ATTENTION, PLEASE. DUE TO ENGINE BREAKDOWN THE SCHEDULED 14:27 SERVICE TO KING'S CROSS STATION IS NOW CANCELLED. THE NEXT SCHEDULED TRAIN WILL ARRIVE AT 17:40 ON THE NORTHBOUND PLATFORM.

MICK

Shit. Just my luck... Say Keith, wanna help me kill some time and flip these discs over at my parent's house?

$\mathrm{KEITH}$

Well, I was just gonna knock you over the head, grab them and run, but yeah, let's do that instead.

(The two gather their stuff.)

MICK

By the way, against my wishes, I'm "Mick" now, not "Mike."

KEITH

You and every other bloke born Michael in England. 
(The now familiar looking BR

Official at the Information Board

turns and tracks their EXIT,

grinning.)

SCENE 3

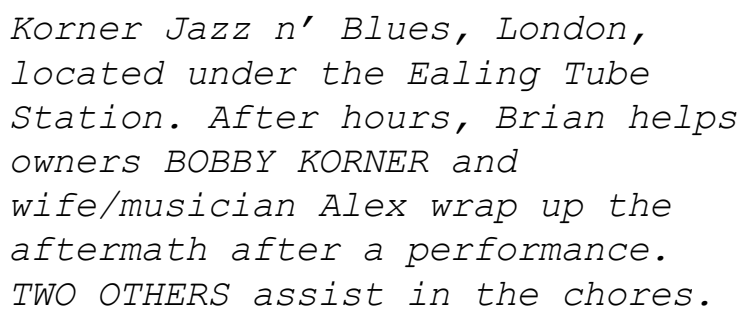

Well, if you ask me, Davies is really starting to milk those harmonica solos a little too much. The next one, I swear I'm gonna put my guitar down and slip out back for a smoke.

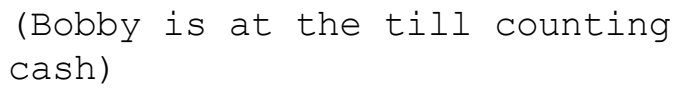

BOBBY KORNER

Well I beg to differ. The kids love it when he gets all sweaty and worked up like a wild man. It exhausts me too, and I'm not even particularly paying that much attention. Two minutes after he's done our lager sales are spiking... Not bad, we cleared over 300 again.

(The crew finishes up and gathers by the front door.)

\section{ALEX}

Hey Brian, c'mon let's go home. You played great, once again, by the way-

\section{BRIAN}

If it's all right, I'd like to stay behind and work on a bit I'm not happy with. Go on, I'll lock up.

$$
\text { (Bobby and Alex share a look) }
$$

ALEX

That's twice this week. You need rest too, kid. 
BRIAN

I swear, twenty minutes, tops.

ALEX

Suit yourself. Bobby will leave a light on for you.

They all exit. Brian sets up a

RECORD PLAYER, playing along with a

particular section that has a RIFF

he is trying to duplicate. He stops

the record and starts over. He

tries twice more without success.

He slumps down in frustration.

THE STAGE LIGHTS DIM TO BLACK FOR

A FEW SECONDS, THEN COME BACK UP.

An hour or so later, sleeves rolled

up and THREE EMPTY BEER BOTTLES

nearby, Brian tries again,

unsuccessfully. He CURSES. In a fit

of anger, he coils as if to smash

his guitar on a BEAM, stopping

himself just short of completing

the task. Again he slumps down.

AGAIN THE LIGHTS DIM TO FULL

BLACK, THEN COME BACK UP.

Brian is now SLEEPING on THREE

CHAIRS he has lined up. We HEAR the record is SKIPPING on the player.

Near his head on a lone chair is a LIQUOR BOTTLE WITH A LONG NECK. On

it's own, the BOTTLE FALLS TO THE

FLOOR, waking Brian up. He swears,

gets up and scrambles over to the

bar and returns with a RAG to mop

up the mess, picks up the BROKEN

PIECES and puts them in a TRASHCAN.

He starts to tidy up and goes to

put away the record. HE STOPS...He

looks back at the trashcan. He

briskly walks over and pulls out

the BOTTLENECK. It's a fairly clean

break. 


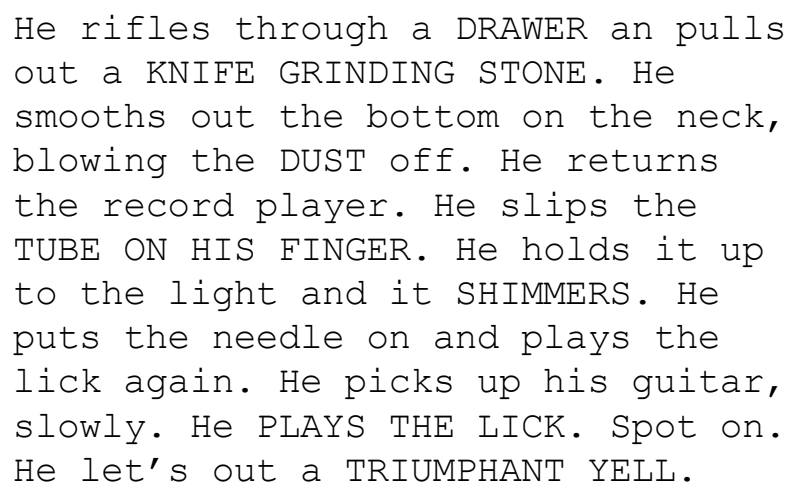

SCENE 4

MICK

That's it, that makes five numbers.

KEITH

Okay, now what do we do.

BLUE BOY \# 1

Easy, we just have to figure out how to put this (picks up TAPE REEL) On this (picks up VINYL).

MICK

Not to worry boneheads, Sir Mick has a four step plan. First we get it to the guy who is in position to get it to a slightly bigger guy who has a hook up with the guy who works for the Big Guy.

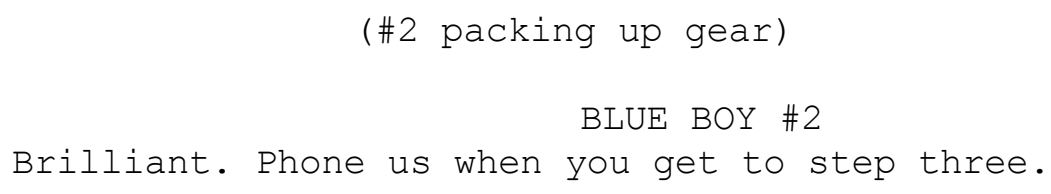


$\mathrm{KEITH}$

You may want to consider labeling that reel with another Band name-

MICK

What's wrong with Little Boy Blue and the Blue Boys? It's got a ring, it says what we do-

\section{$\mathrm{KEITH}$}

Sounds a bit swishy to me. A little too much "blowing" going on there. Maybe something with motion, energy. Something you can actually fit on a marquee... Anyways, back to step One. Who's the guy?

MICK

Female, actually. Alexis Korner of Blues Incorporated. She and her husband just opened the first Jazz and Blues joint that does $R \& B$ in London. I had a great phone conversation with her yesterday. She said to give her a demo. I said we had one. Now we do.

You going to post it to her?

$$
\text { BLUE BOY \#1 }
$$

\section{MICK}

I'm going to hand it to her. Tonight. No time like the present. Who wants to tag along?

(The boys all MUTTER AD LIBS about having other plans, as they finish wrapping up their gear.)

MICK

(Dangling CAR KEYS)

That coupe in the driveway is mine tonight. Got room for one more!

\section{BLUE BOY \#2}

There's a young bloke in her band that plays Slide, I hear.

$\mathrm{KEITH}$

(suddenly interested)

Slide guitar? 
BLUE BOY \#2

Yeah, calls himself "Elmo Lewis." He's got blonde hair. Blonde Elmo Lewis. Sounds like an oxymoron.

BLUE BOY \#1

More like half that; The moron part.

(The others laugh, except Keith.)

$\mathrm{KEITH}$

Hey Mick, I'll run up there with you.

SCENE 5

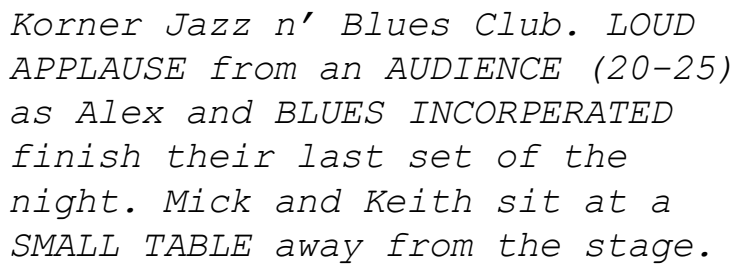

ALEX

(into stage mic)

Thank you. Thank you so much. That was "Dust My Broom", and that was Elmo Lewis over there, doing all the sweeping!

(She gestures to Brian, the applause gets LOUDER and some of the audience STAND. Brian takes a bow.)

ALEX

Well that's it everybody. The last train out upstairs is at 20 after. Goodnight all!

(Some of the crowd start for the exit, others go for last call at the bar. Mick, TAPE BOX in hand, and Keith make their way to the stage.)

Alex!... Alex!

MICK 
(She turns from another band member.)

MICK

It's Mick- we spoke on the phone yesterday. You were amazing. Even better than your records!

\section{ALEX}

Oh Mick, right, the one from LSE, right?

$$
\text { MICK }
$$

Yes, we were in the area, recording, thought we'd pop by . This is Keith Richards, my lead guitarist.

$$
\text { (They politely exchange greetings.) }
$$

ALEX

Mick says you were so good on guitar, it caused him to pack it in and switch to vocals. Would you two like a beer on the house while we wrap it up?

MICK
Actually we've got a gig to go to-

\section{ALEX}

What's still open at this hour?

MICK

It's a private thing, you know, VIP's and all. We're not supposed to say- Oh, here's that demo you asked for.

(Alex accepts the box)

\section{ALEX}

Great. We do a Semi Pro night on Tuesdays. If we like your stuff, we'll call you.

$$
\text { MICK }
$$

Super. Our number is on the back. Thanks again, Alex.

Hold on-

$$
\text { ALEX }
$$

(To Brian) 
ALEX

Hey Elmo, come over here for a minute-

(Brian heads over)

ALEX

This is Mick and, sorry, what was it again?

KEITH

Keith. Richards.

$$
\text { (As they shake hands) }
$$

They're part of the-

ALEX

MICK

Little Boy Blue and The Blue Boys.

BRIAN

Great. Blew as in, which one of you blew the other one?

(Keith tries to contain a "told you so" laugh.)

ALEX

Sorry, Elmo here has tended bar on Open Mic Stand Up one too many times.

(She goes off, tape in hand)

KEITH

Hey, really dug the Robert Johnson, man. That slide is cool.

BRIAN

Thanks. What's your muse?

$\mathrm{KEITH}$

Him, all the others that came after. It's a long list-

BRIAN

Tell me about it- Did she tell you about Semi Pro night?

MICK

She mentioned it as a possibility. 


\section{BRIAN}

You play with a pro, they get the dough. You guys split a semi doughnut... Hey, gotta go, cheers.

(He goes off, Keith and Mick head

out the other way)

MICK

Okay, so maybe we reconsider the name thing.

SCENE 6

102 Edith Grove. A three storey flat in Chelsea. Brian, NEWSPAPER in hand, RINGS the buzzer. He rings twice more, starts walking away. The door flies open, revealing JAMES PHELGE (will be "JIMMY FUDGE"), a chubby 20 year old. He's wearing only tight white UNDERPANTS.

FUDGE

(pissed off)

Yeah, what do you want?

BRIAN

Oh, sorry. Didn't intend to disturb, just inquiring about an advert for "Flatmates Wanted." Must be the wrong place.

FUDGE

You got the right, place.

BRIAN

Oh. "2 Bedrooms, Lounge, common Loo. Phone?"

FUDGE

Yep, that's it.

BRIAN

Right. Well, suppose I could have a look?

FUDGE

Maybe. First things first. There's a process. Application. Hold on. 


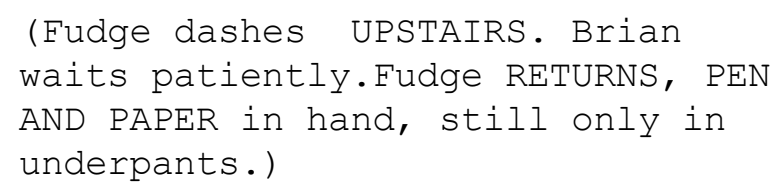

FUDGE

Name, Surname first.

BRIAN

Uh, Jones. Brian Jones. Look, I can come back...

Occupation?

FUDGE

BRIAN

I'm an assistant barkeep and musician. Paid musician.

FUDGE

(writing)

Hmm. Average wages per week?

\section{BRIAN}

The ad says 10 quid a week. I can do that. It also said Nankers need not apply.

FUDGE

I'll explain that in the next Phase. Issues with previous tenants. We can now proceed to Inspection. Any questions so far?

BRIAN

Uh yes. The question mark by the word "phone." Is there a phone in the flat?

FUDGE

Well, not as such.

\section{(He motions to a NEARBY RED}

PHONEBOOTH . )

\section{FUDGE}

That's it over there. On a still night you can hear it ring. The last guy here discovered if you clicked the cradle a certain way you could make free calls. I could never duplicate that, however. 
This way, Mr. Jones

$$
\text { (motioning up the stairs) }
$$

(Brian makes note of the phone and the two go up the stairs.)

SCENE 7

Dartford Train Platform. Mick and Keith are sitting on the bench, waiting for the train to their respective schools. Mick is reading a MUSIC PUBLICATION, Keith is working out some fingering on his GUITAR.

MICK

The problem with a manager in the music business is the main thing they "manage" to manage is to sort out how to screw you out of everything. The Contract Structuring they're allowed to write is absolutely criminal. My Statistical Analysis professor estimates-

KEITH

(interrupts)

Do you reckon cows ever get bored?

What?

MICK

KEITH

When you see a pack of them out the train window. They just chew grass, walk around a bit, have a shit. They've got to be thinking of something. Imagining something.

MICK

(still reading)

What they're thinking of is that fine long-horned stallion of a bull, kicking the stall to get at them...Hey, listen to this Wanted Ad: "Forming a Rhythm \& Blues Band. Need vocals, Harmonica and Guitar. Be willing to rehearse. Plenty of interesting work."

$\mathrm{KEITH}$

That's definitely interesting. 
MICK

Yeah, and get this. The address is the Korner Club under Ealing Station. It's from that guy who played that amazing slide.

KEITH

Him? He was kind of a dick. But yeah, he's really good.

MICK

It's just an audition to play with him, not live with him.

(The boys get up with the SOUND OF

THE APPROACHING TRAIN.)

SCENE 8

Korner Club. Bobby and Alex

Korner are stocking and setting

up the bar, Brian is nearby

helping.

BOBBY

That Edith Grove is a great location. Chelsea is near enough to everything. There's tons of gigs over that way. And you'll always have our place to sack out when you're near here.

ALEX

And don't think twice about leaving my band. You'll always have that spot. You're so ready to take the wheel.

(Brian still wipes the same table. Somethings bothering him.)

BRIAN

Thanks so much. Both of you.

ALEX

(fully concerned)

Is something wrong, Brian? Tell me.

BRIAN

Something I need to get off my chest...Back in cheltenham...there's this girl... 


\section{ALEX}

Brian, I know about that schoolgirl. I know about the adoption. Is that what this is about?

BRIAN

(still struggling)

Well, yes... and...

(Alex puts her hands on his shoulders.)

\section{ALEX}

Look. That's all in your rear view mirror now, Okay? You're going forward now.

(Brian nods. Something's still not right.)

ALEX

I know music is everything to you now. But it's not the most important thing, Okay?

Okay .

BRIAN

(Alex steers in a positive direction.)

\section{ALEX}

Right. Your auditions; Do you want do them here on Sunday mornings? Otherwise Thursday nights you could use the back room area-

BRIAN

$$
\text { (lightening up) }
$$

Thanks, but there's a place down a ways from Edith, the Bricklayer's Lodge. They've got a room upstairs for a few quid.

\section{ALEX}

Cool. Everybody will chip in. I saw your list. There's some decent talent. Ian Stewart, solid piano. Plus, he owns a moving van. Don't worry about rhythm boys too much. My drummer Charlie will come sniffing when there's any kind of money whatsoever. You may want to invite Wyman at some point. 
I hear he's jerry rigged a PA and turned it into a room rattling bass. Those kids who show up on Tuesdays, the Dartford Duo. There's a spark there-

SCENE 9

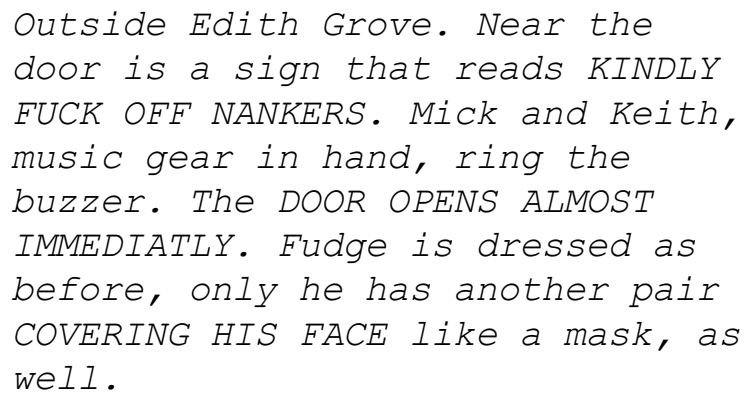

FUDGE

Can I help you?

KEITH

Is Elmo here?

FUDGE

Who's Elmo?

MICK

Brian. Brian Jones. We're here to see him. We're musicians.

FUDGE

How do I know you are who you say you are?

$\mathrm{KEITH}$

We didn't say who we are.

FUDGE

Look. Don't get smart with me. I've seen the list.

(Mick puts out his hand, then

thinks better of it.)

MICK

I'm Mick, this is Keith. We're here for the audition.

FUDGE

Why didn't you say that in the first place, then? 
We did.

FUDGE

No you didn't. Look here fellas, I'm Brian's flatmate. I can't just go letting any Nanker past the door who says he knows some bloke named Elmo, can I? Can't you read the sign?

KEITH

The one that says "Fuck off Nankers?"

FUDGE

No, the one that says the audition has been moved round the corner to the Bricklayer's Lodge.

(He steps out on the porch, surveying.)

FUDGE

Shit- somebody must have nicked it. More likely than that, Brian probably forgot to put it up. I spent the better part of the morning making him a nice detailed map with fancy arrows- Brian's a bit forgetful-

KEITH

Sorry to interrupt, but could we just get the address?

FUDGE

Look, it's really quite simple. Left down to King's Road, go right. Three doors down. Sorry, don't have all day, lads, okay? I've something on the burner.

\section{(He slams the door.)}

MICK

Well there's two minutes we'll never get back. It was like being trapped in a BBC comedy sketch.

\section{KEITH}

(As they EXIT right.)

Do you have the feeling this whole thing is a complete waste of time, like me? 
SCENE 10

\begin{abstract}
A ROOM ABOVE the Bricklayer's Lodge Public House. There's a TABLE to one side with TWO DOZEN BLUES ALBUMS and a PORTABLE TELEPHONE. The BAND has just finished up a number, SWEATY from playing for a while. IAN STEWART is behind a STANDUP PIANO dressed like a TYROLIAN MOUNTAIN CLIMBER. Mick sits on a stool, microphone in hand. Brian and Keith stand next to each other. A BASS PLAYER and a DRUMMER with his KIT are off to the side. MANY PINT GLASSES filled to various levels decorate the room.
\end{abstract}

BRIAN

Okay, we've got that one halfway decent, thank you Ian, for sorting out the whole middle part. Let's have a piss break, I've got to check in with the office.

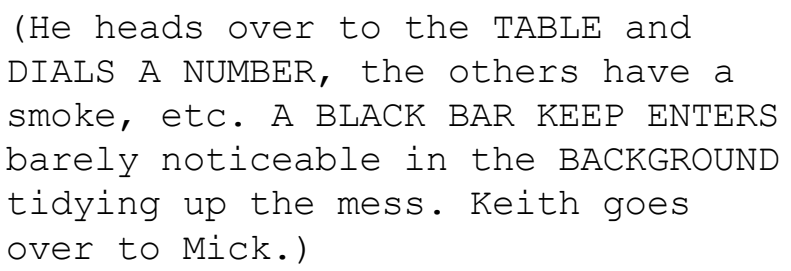

KEITH

Shit, I can barely keep up with him.

\title{
MICK
}

Yeah, I noticed. Not a bad thing, right? You're always talking about that guitar weaving thing-

\section{KEITH}

What's with the piano. I mean he's super good, but Lederhosen? Do you think he's gonna have us yodeling at some point?

(Brian can be heard from the table.) 
BRIAN

Hold on Bobby, give a minute-

(covering mouthpiece)

Hey boys- Blues Incorporated just got a booking for a BBC live broadcast. They' re asking if $I$, that would be we, want their Saturday spot in the line-up. Ian?

IAN

Are you kidding? No fucking way. We're a whole postal code away from being ready.

\section{BRIAN}

Yeah Bobby, of course we'll take it.

(The others surround the table, except for Ian.)

BRIAN

Yes. Hold on, let me check with the boys. (covering mouthpiece again)

They need a band name for the Union paperwork. Any suggestions?

(Crickets. He motions to Keith to give him a PARTICULAR ALBUM.)

BRIAN

Yeah, that Muddy.

(He flips it over to the backside, fingering a LINE.)

BRIAN

Got a pen? (beat) The Rollin' Stones. R O L L I N apostrophe. Yes, Stones like a rock.

(All the others show their

approval, except for Ian.)

BRIAN

They need an address for the ledger. Should I give them the Edith Grove?

MICK

No fucking way. If someone smashes something up, you, slash we, get the billing. Make something up. 
BRIAN

Nice, LSE boy, I knew that would come in handy-

(Keith hands him ANOTHER ALBUM.)

BRIAN

(finding something)

Put the band's address as Crossroads. Number 27.

(They others contain laughs.)

BRIAN

London SW 19. There is no 19? (pauses) Sorry, meant 15. One pint too many. Hey, my love to Alex... Cheers.

(He hangs up, the room buzzes with

energy.)

IAN

That's like the worst band name I've ever heard of, but it's your party, Brian.

\section{BRIAN}

I don't remember hearing anything from the piano when I asked, Debbie Downer.

MICK

Hey, It's a working title. Like a place holder. It's not like we're stuck with it for fifty years.

BRIAN

You two are gonna need a place to stay, everybody else lives here. As Ian optimistically points out, we've got a shit ton of rehearsing ahead. You can stay at my place, there's plenty of room.

KEITH

What about Sergeant Underpants?

\section{MICK}

We met your flatmate on the way over; You sure he's okay with this?

BRIAN

Jimmy's harmless. But you may have to fill out an application. 
RRN M F N euromuscular J ournal

54.

END OF ACT III 


\section{ACT IV}

SCENE 1

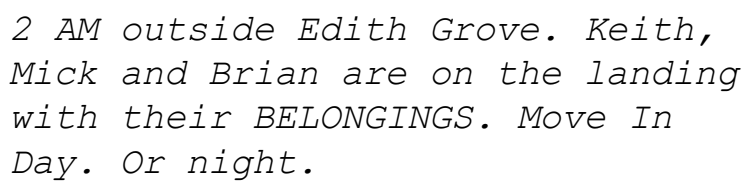

BRIAN

Shit, I totally recall grabbing it on the way out. (He RATTLES the door knob.)

MICK

Is there a back way?

BRIAN

We're on the middle floor. Windows are too high. Tried it.

$\mathrm{KEITH}$

(calmly)

Check your inside jacket pocket.

(He does, pulling out some stuff, his asthma SPRAYER, slide TUBE, a KEY. He tries the key, but it DOESN'T WORK.)

BRIAN

Bollocks, grabbed the wrong one.

May I?

KEITH

(Keith tries it a couple times then

gives it back. He KNEELS and

inspects the hole briefly and

produces a PICK from a pocket. He

POPS OPEN the door.) 


\section{KEITH}

A leftover from my misspent youth.

(The boys gather up their stuff and head up. There's SUDDEN SWEARING and BAGS TUMBLING as they scramble back OUT amidst a YELLOW STREAM. Someone on the landing is PEEING on them, with plenty of ammunition.)

BRIAN

FUDGE ARE YOU FUCKING KIDDING ME? YOU FUCKING WANKER!

(They're soaked, but do sense the humor. Kinda. LIGHTS go on.)

SCENE 2

Inside the DUMPY FLAT, the boys are toweling off. Sargent Underpants is in his usual attire.

FUDGE

Put yourself in my position. Voices wake you up, you hear the lock being fiddled with multiple times. There's been reports of break in's of late.

BRIAN

I can see your concern. Thieves have heard about your valuable Perry Como record collection, waiting to pounce at just the right time...

FUDGE

Hey, that 178 is extremely rare.

\section{BRIAN}

And why do you think that is? They've all been tossed out... Just don't fucking do this anymore, Okay?

\section{FUDGE}

Got it. Not to belabor the point, but lacking a proper weapon, it was quite resourceful. And effective. 
BRIAN

Okay, enough said, moving past. Mick and Keith here are going to be staying here for a few days, maybe longer. If it works out, maybe we could split the rent four ways, reducing our cash flow issues by half.

\section{FUDGE}

Wow. This is kind of awkward. Maybe you could have brought up this proposal in a more discreet setting.

\section{BRIAN}

Apologies, my mistake. Just trying to put the application process on a faster track. Shall we give her a go?

\section{FUDGE}

Yeah, I guess that would be okay, the tryout thing. We'll have to tweak the floor plan a bit.

$$
\text { (getting up) }
$$

The loo on the landing you're already acquainted with. Let's start with a tour of the kitchen facilities.

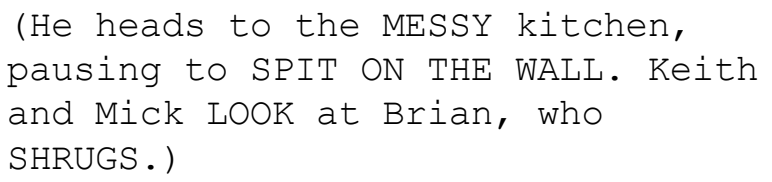

SCENE 3

The Same. Day. Keith and Brian

are fiddling with their GUITARS

and sipping TEA, Mick has his

head in an ECONOMICS BOOK. Fudge

ENTERS, fully dressed for work.

FUDGE

All right gentlemen, I'm off to the print shop, on the afternoon shift now.
MICK
(barely recognizing)
Who the fuck is that?

FUDGE

This is work mode Jimmy. As in job. As in something you Nankers don't have. 
BRIAN

As in off you go, Earnie. Have a nice day, luv.

$\mathrm{KEITH}$

What's the difference between a "Nanker" and a "wanker"?

FUDGE

Ha. Figures you wouldn't know. A Nanker is one who goes to Wanker School, only he's dropped out because he's a total nitwit.

(He makes the FULL NANKER FACE.)

FUDGE

An "Earnie" is just your average working slob, a brainless lemming who follows all the others just trying to earn enough for some bangers $n^{\prime}$ mash. Brian here has just used the term in a sentence. Only I'm not one. A sentence with Nanker might be: I hope you two Nankers have moved out by the time I get back from work.

(He makes the Nanker face again and EXITS.)

MICK

I get it. That's why he runs around in dirty underpants. He's desperately trying to not become an Earnie. It's like a Superman costume sans the cape.

$\mathrm{KEITH}$

Yeah, that actually makes sense. Kinda.

BRIAN

It scares people away. All the neighbors think he's a whack job and totally avoid him.

\section{MICK}

(getting up)

Well, I've an afternoon class, campus is conveniently close by, thankfully.

$$
\text { (He starts to get dressed.) }
$$

KEITH

...Speaking of classes and dropping out, I've decided to quit Sidcup. 
MICK

What? That's a drastic step. We've done like three gigs-

$\mathrm{KEITH}$

All Sidcup leads to is some wanker coffee fetcher job at the J. Walter Thompson Agency. If you're lucky, you get to draw up some soap advert of a housewife exclaiming how white her hubby's shirts came out in the wash. Or some fancy bloke bragging about his brand of cigarettes. I'm sorry, but there's little or no satisfaction there. Not to mention it's starting to seriously interfere with my drinking and guitar research. I think my colleague here would concur.

\section{BRIAN}

At the risk of providing a bad example, it seems to work for me.

\section{MICK}

Well I'm a firm believer in the notion of keeping a foot in both places until you're absolutely certain it's safe to jump. All these classes will pay off one way or the other at some point, either way.

\section{$\mathrm{KEITH}$}

I've made a pact with my guitar. I'm gonna follow her wherever she may lead. At least for now... (to Brian) C'mon let's work on that handoff again...

(They get back to it as Mick collects his books and EXITS.)

SCENE 4

The KITCHEN AREA of the flat. UNWASHED POTS AND PANS are PILED $H I G H$ in the sink. Fudge is STANDING on a chair, DRAWING a CIRCLE around an area he has previously spit ("gobbed") and labeling it, apparently. Keith ENTERS.

What the fuck are you doing? 
(He puts a kettle on for coffee.)

FUDGE

Tradition. If you gob one really good and it sticks, it gets a name, like a classified hurricane. This one is Green Humphrey .

$$
\text { (pointing around) }
$$

That one over there is Bloody Morris. In the front room hangs Brown Sugar.

$$
\text { KEITH }
$$

You're disgusting.

\section{FUDGE}

I've noted you're not exactly afflicted by the Anal Retentive Syndrome either. How about channeling some of that excess energy into the washing up?

\section{KEITH}

All right you depraved Nanker. I'll knock this out twice as fast as you ever could.

(Keith dives in. This is gonna take forever. He shoves a GREASE PACKED FRYING PAN at Fudge.)

KEITH

You do that one.

(Fudge accepts the task, but doesn't have much success. Frustrated, he OPENS A WINDOW AND TOSSES OUT THE PAN.)

\section{FUDGE}

That pan was really starting to piss me off. Plus, it's supposed to rain really hard tonight-

(Keith admires the thinking and the both of them laugh as they TOSS THE REMAINDER of the pans into the backyard.) 
SCENE 5

The Same, next day. The Kitchen
is COMPLETELY TIDY with the pots
and pans NEATLY STACKED. Brian is
having a coffee. Keith ENTERS.

(He looks around, confused.)

KEITH

I'd thank you, but I know it's outside the realm of possibility. Who did all this?

\section{(Fudge ENTERS.)}

BRIAN

I thought you two did.

FUDGE

We started to, but didn't quite see it through to completion.

KEITH

(concerned)

Shit. You don't suppose it was the landlord's wife who scooped them up from the backyard?

BRIAN

Backyard? Look, if she did anything at all, believe me we'd have heard about it long before now.

FUDGE

Maybe Jagger did 'em. He's the clean one.

$\mathrm{KEITH}$

(yelling)

Mick, come in here!

ENTER Mick.

MICK

Yeah what?

Did you clean up the kitchen? 
MICK

Not directly, but yes. Priscilla, the nurse from downstairs said she found those all over the backyard. She washed 'em all up and them brought them up. I helped stack. She tidied up while I sang her a song with her name in it. You have no idea how hard it is to fit the name Priscilla gracefully into a verse.

\section{BRIAN}

See, I'm telling you; Music is like currency.

\section{KEITH}

Cool. Thought it was the landlord's wife.

\section{MICK}

Speaking of whom, he's due to come round today for rent. Give it to me now and I'll run it by his shop on my way out. Maybe we can avoid him barging in, again, in the midst of a compromising position. Brian.

\section{FUDGE}

Getting paid today, I'll have it tonight.

KEITH

Spent my last bit on our new gitty strings-

BRIAN

Skinned.

MICK

Right. Being the only one with a checking account, I'll write a check which is bound to bounce as high as an overhead smash at Wimbledon.

(Mick has pulled out his CHECKBOOK.)

\section{$\mathrm{KEITH}$}

While you're at it, can I get one too?

MICK

Sure. How much would make you happy, Mr. Richards?

$\mathrm{KEITH}$

(calculating)

A nice round one million pounds. 
(Mick writes a check, Slaps it on

the TABLE. Keith picks it up.)

KEITH

"Pay the Bearer One Million Pounds"

(They all laugh, Keith slaps the check down.)

FUDGE

Damn, wouldn't that be nice though.

MICK

Hey don't laugh, I read somewhere that over in the States, California I think, someone presented one just like that, and the bank accidentally cashed it-

(There's a BEAT, then the OTHER

THREE DIVE to get the check, shoving and wrestling. Mick enjoys

the last laugh.)

SCENE 6

Outside the flat, the band, including Ian, BILL WYMAN and CHARLIE WATTS are bringing MUSIC GEAR out of the flat and staging it by the curb. Ian and Brian are standing STAGE RIGHT, next to the PHONE BOX.

BRIAN

Can you front me a shilling? I'm gonna book us for a session.

IAN

(reaching into pocket)

You really think you and the Three Chord Wonders are ready for that?

BRIAN

Nothing ventured nothing gained. 
(Ian gets distracted by gear

activity.) Brian POCKETS THE COIN

and CLICKS THE PHONE CRADLE 4 TIMES

IN SEQUENCE. He gets DIAL TONE and

dials a number.)

\section{BRIAN}

Hello, this is Brian Jones, we spoke earlier, I'd like to go ahead and book that slot on Friday if it's still available...It is? Magic, you're the best, luv...Method of payment?

$$
\begin{aligned}
& \text { (LOOKS at Mick, who's } \\
& \text { bringing gear down) }
\end{aligned}
$$

That would be by cheque, please...You don't take cheques from musicians?... I see, no problem, I don't blame you. Got it, cash only. Right then, see you Friday!

\section{( Ian returns.)}

IAN

I saw that. Give me my $10 \mathrm{p}$ back.

$$
\text { (Busted, he RETURNS the coin.) }
$$

IAN

How'd you do that?

BRIAN

$$
\begin{aligned}
& \text { (makes sure others can't } \\
& \text { hear) }
\end{aligned}
$$

Easy, just click the cradle three quarter beats and one half beat. Free calls forever...Don't tell the others, It's a steady source of income.

CHARLIE WATTS

Hey Ian! Get the bloody van, we're gonna be late-

$$
\text { (As he exits STAGE LEFT.) }
$$

IAN

Is it my fault you have to park two blocks away every damn where you go in Chelsea?

BILL WYMAN

Hey, why does your stairway reek of piss? 


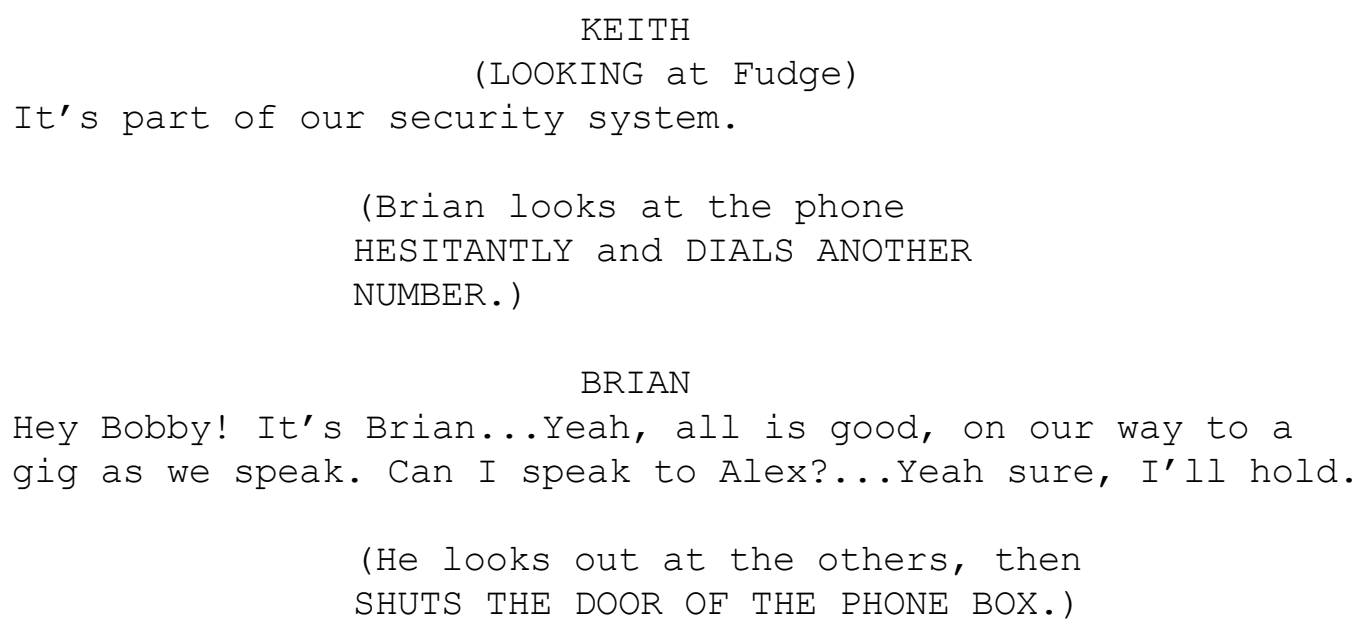

SCENE 7

All four are back in the flat. A MICROPHONE DANGLES underneath the center light.

BRIAN

Okay, so I've got some great news and some not so great news. Which first?

MICK

Why do I get the feeling that the Less Than Great news is going to involve me writing a cheque?...

BRIAN

The excellent news is I was able to book Glyn Johns to mix 5 songs for us tomorrow. I pulled some favors and got a super low rate. Gentlemen, we're gonna be on vinyl.

(The others are impressed.)

MICK

Well done. So what's the special rate?

BRIAN

Fifty. You guys split it up; That's a tenner each.

MICK

For all six band members it's eight pounds thirty three and a third. That's not too bad. 
$\mathrm{KEITH}$

Much too good to pass on. We gotta figure out a way. Probably won't take a cheque from the likes of us.

FUDGE

I'll do a share.

BRIAN

Aw, cheers, Jimmy.

FUDGE

Look, I'm just trying get rid of these guys as soon as possible. So what's the bad part?

BRIAN

The bad part is I'm not sure we'll be welcomed at the Korner club for a while. Alex is pissed at me. It involves my past.

\section{(Silence.)}

BRIAN

I had to tell her about (GIRL A) and the kid.

MICK

Wait a minute, I thought it was (GIRL B) with the kid?

BRIAN

Well, yeah, there's her too...

FUDGE

Including your school girl episode that makes THREE!

(Brian nods. The boys are taken aback.)

\section{KEITH}

Christ Brian, you've knocked up enough for the entire band! You've used up our entire allotment. Wow. Prolific. This is why I sleep with my guitar. You should try it-

\section{FUDGE}

Pan the mythological half goat Flute playing bird magnet god didn't bag as many by age 20 !

MICK

And you've just now told Alex? 
BRIAN

I tried to tell her before, but there was a lot of other stuff going on.

$$
\text { (Silence Again.) }
$$

FUDGE

Crap... This is like in a Shakespeare play, in Act 4, when all the bad shit happens... Well the good news/bad news thing here is, in the final act, you either get crowned King, or, it all ends in a double suicide...

(The others give him a deadpan look.)

FUDGE

Hey guys, you weren't the only one's who went to school.

SCENE 8

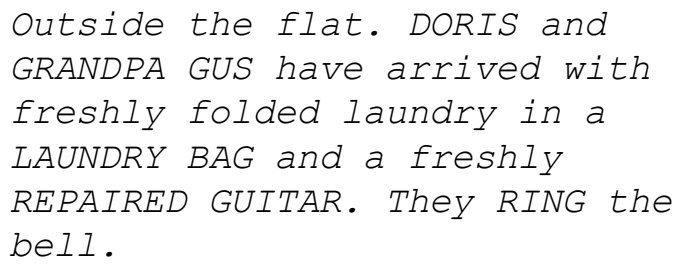

DORIS

This time no fiddling around; Last time you took 20 minutes.

GRANDPA GUS

I had to fix two guitars! I thought it went pretty fast-

DORIS

Bill's going to circle the cab around the block twice, then scoop us-

GRANDPA GUS

Good thing you have a...friend, who owns his own taxi cab, else we'd be broke.

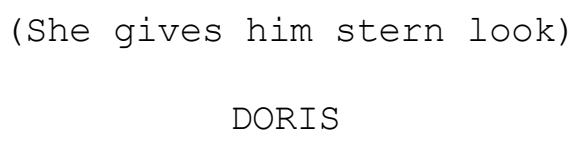

DORIS

Bill's been extremely kind. Be nice to him. 
(Footsteps are heard, the DOOR OPENS and Keith ENTERS.)

$\mathrm{KEITH}$

Mum! Gramps!

(Hugs and kisses all around. Gus presents the REPAIRED GUITAR.)

KEITH

Looks like the day I bought it! And fresh laundry! You guys are the absolute best! C'mon up and say hello to the lads-

(Keith bounds UP THE STAIRS with

his booty. Mum and Gus follow as

she gives him the CUT SIGN as they

DISAPPEAR. GREETINGS AND VOICES OF

ALL SIX ACTORS ARE HEARD,

PUNCTUATED BY DORIS.)

DORIS

(Just offstage)

Sorry, got to go! Cab waiting!

Doris and Gus RE ENTER from the

stairway, Gus with a new SOILED

LAUNDRY BAG, ANOTHER BROKEN GUITAR,

and HOLDING HIS NOSE. They walk to

the curb.

DORIS

I'll never enter that pigsty again if I can avoid it.

GRANDPA GUS

My god, going up and down that staircase is akin to walking through the men's latrine at Wembley!

DORIS

...I've never seen that odd boy in anything else but his underwear... What's his name again?

GRANDPA GUS

They call him Fudge, and I'm not going to ask why. Just another fine product of our British educational system. We can really churn them out. 
DORIS

There's Bill coming up now- The broken guitar can ride up front, but that foul smelling bag goes in the boot.

SCENE 9

Inside the flat, almost bedtime. Mick is exercising, Keith is fingering his guitar, and Fudge is doing God knows what. BOUNDING FOOTSTEPS come from the stairwell and the DOOR FLINGS OPEN.

(Brian ENTERS out of breath, PACKAGE IN HAND, RIPPING IT OPEN.)

BRIAN

Here it is! It's still warm from the pressing-

(He HOLDS UP a plain white ALBUM JACKET for all to see. The others stop what they are doing and SURROUND him as if they are seeing a newborn for the first time.)

MICK

Let's spin that baby right now-

(He GRABS the record and goes towards the turntable. Keith INTERCEPTS IT.)

$\mathrm{KEITH}$

Wait a minute. Let's savor this for a moment. This is like our first born-.

(He carefully handles the record as he REMOVES IT from the jacket. He HOLDS IT UP TO THE LIGHT.)

\section{$\mathrm{KEITH}$}

Do you see that virgin groove? It will never look the same again. It's one long line, from beginning to end, cut by a diamond. Every microscopic hill and valley is carved by our instruments and voices. 
(He hands it carefully to Brian.)

BRIAN

It is a thing of beauty. There is a lot of sweat and blood on those tracks.

(He hands it to Fudge.)

FUDGE

Looks like a record to me.

(He hands it back to Mick, who carefully puts it back in the jacket.)

MICK

Keith is right. We can't hog this moment. The rest of the band needs to be present. At the very least we should phone them and tell them. Give them a call, Brian-

BRIAN

Agreed. All for one; One for all. Anybody got any coins?

FUDGE

Oh, you don't need any coins anymore! All you have to do is tap the cradle four times; Three quick ones then one long one, then you get dial tone!

BRIAN

Wait, what? How did you-

FUDGE

Charlie told us. He and Wyman made a shitload of calls. Ian showed them how. It works every time!

(Mick and Keith chime in to confirm)

BRIAN

(Exiting)

No secrets in a band.

(He EXITS to stairwell)

FUDGE

While we're waiting, I'll put some music on. 
(He rifles through a NEARBY STACK.)

FUDGE

By the way, has anybody seen my Perry Como records lately? Keith?

Keith and Mick fight off grins.

KEITH

Can't say I have. Not a massive fan of his.

FUDGE

That's funny, because the nurses downstairs said they found some records in the backyard. Said they had to bin them because they were so badly warped by the sun... Strange that someone would toss them there in that manner... Why would anybody do something like that, Mick?

MICK

There's no accounting for taste and such. That couple in the flat above us are a bit "off", wouldn't you say, Keith?

$\mathrm{KEITH}$

I've noticed. The offer couple. They always seem to be arguing. Throwing things around...

(Brian RE ENTERS)

BRIAN

Wyman and Charlie said they could swing by tomorrow. Ian said he doesn't care one way or the other; He already knows as he was there. If the three of us say yes, then we have a majority-

MICK

Yeah. I don't know, man. Now I feel guilty. What say you, Keith?

KEITH

Shit. Put it on me then. I want to hear that thing right this second too, but, like you say, this is a precedent setting moment. If we're gonna run like a pack, then we eat as a pack. 
MICK

Well, I guess that settles it, then. We go to bed, and the six of us play it tomorrow...

(The all stare at the record for a beat, then peel off each to their OWN BED. They all prepare for sleep in their OWN WAY. Each glancing over at the RECORD PLAYER. The LIGHTS GO OFF and the STAGE GOES DARK. Then-

(Keith's VOICE)

OKAY, FUCK IT! LET'S PLAY IT!

$\mathrm{KEITH}$

(The LIGHTS SNAP BACK ON and ALL FOUR SCRAMBLE OVER to the record player hastily putting THE RECORD on. We HEAR a few introductory NEEDLE CRACKLES...)

SCENE 10

The Same, weeks later. Brian is POLISHING HIS BOOTS while sitting on HIS BED. Mick is studying, Keith is walking around eating out of a CAN OF BEANS. Fudge is in $B E D$, sleeping.

BRIAN

It's a really good record, I mean the vocals may be a little too much in the foreground and some other minor issues. But it's been almost a month now, and we can't hardly get any one of those tracks to get any radio play.

\section{MICK}

It does help if you've got a record label who's got DeeJays all over the UK on the payroll. That's what got the Beatles over to the States. I mean look at them... And the vocals are perfectly balanced, by the way. 
BRIAN

Screw those arseholes and their bouncy Buddy Holly music. The Labels just want to put you in a uniform, give you all the same cute haircut, like a bunch of cuddly Teddy Bears. (Mimics) She loves you, yeah, yeah, yeah-

\section{KEITH}

(eating beans)

The difference is, people sing along with that shit. When we play in a club, people get off their asses and move. Unfortunately that's hard to see on a radio...

(To Brian)

\section{KEITH}

Hey, you know you're spilling that polish all over the place.

BRIAN

(taking notice)

Shit! How do I clean that stuff out!

MICK

(nose still in book)

There's a bottle of kerosene on the heater. Use a rag to get it out.

Brian fetches the KEROSENE and a RAG from the kitchen. He RUBS the stain.

BRIAN

You're right, but this reeks to high heaven-

(He puts KEROSENE BOTTLE down on

the corner of the bed, and rubs

some more. The bottle FALLS

spilling ALL OVER the bed.)

BRIAN

Crap! I'm an idiot!

KEITH

You bloody Nanker! The whole place is gonna stink to high heaven! 
(Keith RIPS THE COVERS OFF THE BED, goes in the kitchen, and tosses the covers OUT THE WINDOW.)

\title{
BRIAN \\ (frustrated)
}

I hate this fucking place. We're nowhere closer. Have we hit the peak? It sure doesn't feel like it. I say we give it three more months, and if nothing happens by then, we try something else.

\section{MICK}

That is, if we have the resources to stretch it to that long.

(The doldrums start to set in.

Keith COMES from kitchen with THREE

BEERS . )

\author{
KEITH \\ (trying to lighten the \\ sobriety)
}

Relax lads. Put a hold on the doom and gloom. Let's have us a libation or two and discuss these matters further.

(They all TAKE A BEER BOTTLE saying

"cheers". Fudge starts to SNORE.)

KEITH

I mean what kind of bluesman worth his salt turns around after a couple of potholes on the road? Keep rollin' up Highway 61, right?



BRIAN

Why not just dump some water on him-

\section{KEITH}

Too easy. The Dartford Dragon would do the trick.

MICK

(laughing)

Now that would do it. But no... 
BRIAN

What's the Dartford Dragon?

(The snoring STARTS UP AGAIN. Keith

STANDS UP.)

MICK

No Keith, No.

(Brian is now fully intrigued. The snoring continues)

$\mathrm{KEITH}$

Can you hand me that box of matches, please, Mr. Jagger?

(Mick shakes his head as he reluctantly hands him the BOX OF MATCHES. Keith walks over to the snoring Fudge.)

KEITH

Ladies and Gentlemen, may I present to you, for your viewing pleasure, The Dartford Dragon-

(Keith DROPS HIS PANTS and CROUCHES, his butt close the source of the snoring. Keith STRIKES A MATCH. )

Drumroll, please.

KEITH

(Brian obliges, DRUMMING ON THE

TABLE. Keith moves the match behind as he LET'S OUT A HUGE FART, WAKING

UP Fudge who IMMEDIATLY BITES KEITH'S ASS. Keith YELLS, falling away and DROPS THE MATCH.)

KEITH

That little shit took a bite out of my ass! God damn!

(Mick and Brian are laughing their asses off. Brian notices the RUG IS SMOKING. Keith, still in some pain takes no notice. 


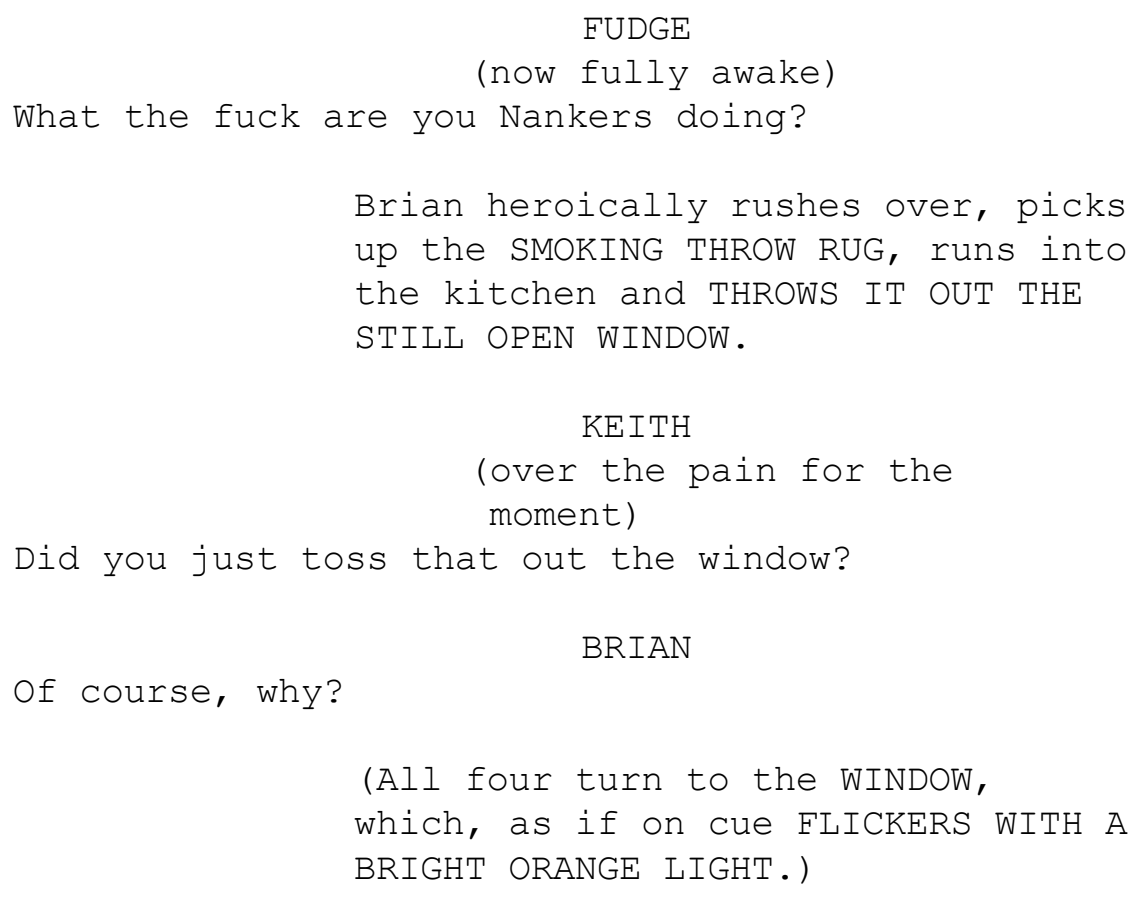

END ACT IV 


\section{$\underline{\mathrm{ACT} V}$}

SCENE 1

$$
\begin{aligned}
& \text { A POSH PRIVATE VIP BAR in a major } \\
& \text { London Music Venue. A DOZEN well } \\
& \text { dressed heavy hitters enjoy NICE } \\
& \text { COCKTAILS. Through a SIDE DOOR } \\
& \text { ENTERS THE FAB FOUR, fOllowed by } \\
& \text { a FEW ENTOURAGE. It's a quick } \\
& \text { break between sets, and they've } \\
& \text { come to slam a quick one. }
\end{aligned}
$$

(The four approach the bar, where

the BARKEEP already has their

drinks prepared. They stand.)

JOHN

I thought Ringo was a goner for sure; Those two birds dashed right past me like I was in their way. If the one didn't trip over my cable they'd have ripped him right out of his drum kit!

PAUL

Trip? I saw you lasso her feet! Nice one. Whipped it around like a champion fly fisherman. Good thing she didn't fall off the stage.

JOHN

Yeah, can you imagine the press?...So where are we clubbing after? Anybody hear of anything half way decent?- I can't bear one more joint with yet another copycat outfit. It's like mushrooms popping up everywhere after a spring rain.

(A DAPPER BLACK MAN who has been sitting next to John with his BACK TURNED, SPINS On his BARSTOOL. We know this guy. Politesse, wealth and taste.)

DAPPER MAN

I'm sorry for eavesdropping, but if you guys are looking for a joint that's really jumpin', I know of a place. 
JOHN

I'm sorry sir, have we met? I'm sure I've seen you before, right?

DAPPER MAN

Maybe. Would have been a while back. Used to play guitar, the Blues. I'm long retired and in a different line of work. More lucrative, as they say...Anyways, you guys gotta get back on stage, so I'll make it quick; The name of the place is The Crawdaddy, it's up Richmond way. The band up there is pretty good.

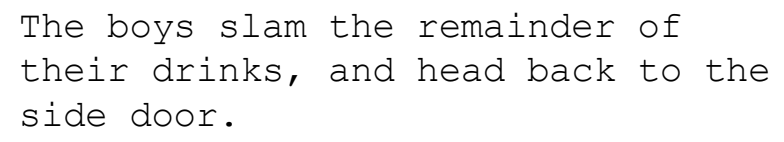

SCENE 2

The Crawdaddy Club. The Stones are FINISHING UP the second encore, Mick STRUTTING AND MOVIN' like he does. The room is filled with SWEATY KIDS who are MOVING TOO. As the song ends, the room ERUPTS INTO A STANDING OVATION. 


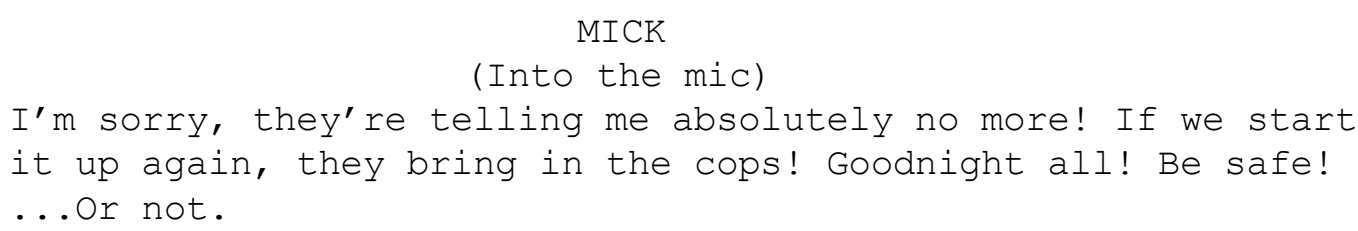

(The crowd HISSES AND BOOS, but slowly complies. ALEX APPROACHES the stage as the crowd starts to filter out, giving Brian a HUG.)

\section{ALEX}

Clearly you guys have outgrown the Korner! This place is twice the size. C'mon, I wanna introduce you to some guys you may know of-

(In a CORNER, a GROUP OF 6 FANS
CLEAR OUT, REVEALING THE FAB FOUR,
COOIY LEANING UP AGAINST THE WALL.)

MICK

Yeah, we heard they were here-

(They approach the corner.)

\section{ALEX}

Rollin' Stones, meet the Beatles.

(The ten exchange greetings awkwardly, ADLIBS abound as they complete the process.)

\section{PAUL}

They told us it would get a bit hot and sweaty in here. Wow. You really got em moving. Almost jumped out there myself. Well done-

$$
\text { MICK }
$$

Cheers. Our motto is, if they're not drenched at the end, we probably screwed something up.

JOHN

Dig the playlist. Do you ever try any of your own stuff? 
BRIAN

Talked about it, but mostly we cover the proven stuff with our own spin-

\section{RINGO \\ (interrupting)}

I'm sorry boys, but I'm parched. How's about we continue all this in wetter conditions?

\section{$\mathrm{KEITH}$}

Shit, nothing open anywhere at this hour. What do you say we commandeer a couple of cases and bottles from the bar and head over to our place? Chelsea's not too far for you, is it?-

$$
\text { JOHN }
$$

Yeah. We're not done yet, right guys? (to his crew) It's either we get some drinks, or just settle it all and square off with a fight right here. Mop Tops versus Bad Boys. Superman versus Batman-

$$
\text { (laughter) }
$$

Since you've got a two man advantage, we'll just have to settle for outdrinking you.

KEITH

Challenge accepted; onward to Edith Grove.

SCENE 3

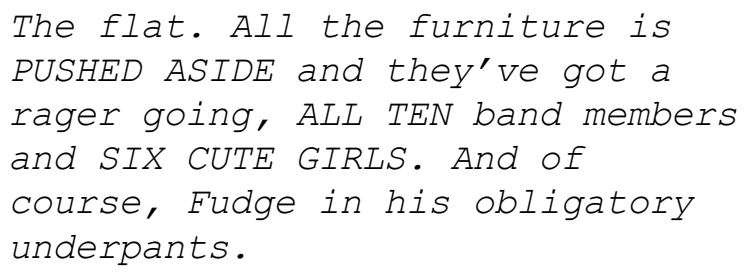

(Paul, Keith, Brian and John surround the TABLE WITH THE RECORD PLAYER and TWO DOZEN RECORDS, which they thumb over.)

PAUL

Explain something to me, Keith. Why do you open an umbrella, then enter the building? 
(He looks at Fudge, who's DANCING

with one of the girls.)

KEITH

For whatever cause, there's a pipe that sometimes sprays a leak over the stairs late at night, for some reason-

PAUL

Get the landlord to hire a plumber. While he's in there, it smells like you have a loose sewage pipe, too.

(Brian gives a record to John. Mick

has come over.)

JOHN

Put on another Jimmy Reed? We've just done two sides. Got any other Wolf's?

BRIAN

What's wrong with Jimmy Reed. I thought you said you like his cadence?

JOHN

I do, but let's go somewhere else for a minute.

BRIAN

(annoyed)

Oh, like some Buddy Holly? Something really bouncy...

JOHN

Okay, I see where you're going with this. What I meant earlier, was that you guys are so much more than just a cover band. In a way, I would really like to go your path. I mean, we want to hold your hand, while your style can sing about spending the night...

\section{KEITH}

Yeah, you're right. Celebrate the taboos. The Blues element allows you to be happy and sad, both at the same time.

PAUL

Write about the stuff around you. I mean look at all thisTalk about your wants, your needs-

MICK

When did you start writing on your own? 
PAUL

Just like you, we were a cover band for too long over in Hamburg. One night we just took the next step, wrote our own ditty. It was just okay. But it opened the door.

JOHN

Your lot has been too long in Hamburg. Blend those Blues in with your own songs. Time to jump-

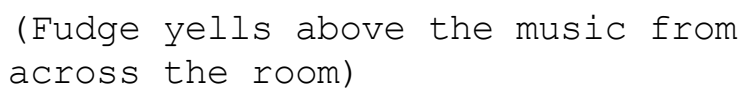

FUDGE

Hey Keith! Ringo and George here don't know what a Dartford Dragon is! Why don't you come over and show them!

\section{(Mick and Keith laugh.)}

PAUL

Dartford Dragon?

KEITH

You really don't want to know.

SCENE 4

Outside the flat, dawn breaking. John and George wait for a cab. Fudge is having a smoke, now wearing a JACKET.

GEORGE

Bloody hell! I've got to be at the BBC in 45 minutes!

JOHN

You're kidding! Management booked that?

\section{GEORGE}

That stupid song competition show. I'm a judge, with some lame muckity muck from Decca Records.

JOHN

That sod? He's an idiot. We'll have to jerk his chain...Hey Fudge, give us a smoke for the road... 
(Fudge passes two cigarettes.)

JOHN

Cheers. So tell me again why it smells like piss out here?

FUDGE

Wolves and defendant dogs have been successfully using it for like 15,000 years. It's two fold; First, it establishes domination over intruders. It's like they smell your piss and go away. Statement. This is my territory. Best you keep moving along, mate. When you piss on top of another dog's piss, you're making a challenge. We're just staking this territory to the stones... The other part of it is for navigation purposes. Like a marker. I can find my way to the front door in total darkness. Simply put, deep down, we're all just dogs, really...

(The LIGHTS OF THE CAB pass over)

GEORGE

(waving)

That's us now-

(John hesitates.)

JOHN

Hold the cab, I'll be right there.

(George EXITS. John walks over to the building, turns his back to us, UNZIPS and PEES. He zips up.)

JOHN

Until we meet again, Mr. Jimmy.

(Fudge waves them off. Keith comes BOUNDING DOWN THE STAIRS and out the door.)

$\mathrm{KEITH}$

Where'd they go? I wanted to see them off-

FUDGE

They all just left...Lennon just took a long piss, right over there. 
KEITH

What? Let me guess; You went on about that dog piss theory of yours, did you?

FUDGE

Yep. He was rather defiant in his manner. He seemed to have a particular spot in mind.

$\mathrm{KEITH}$

That bloody Nanker.

(Keith goes over to the spot, and

PEES. When he's finished, Fudge

does the SAME.)

FUDGE

Stone's Territory. Just making sure.

$\mathrm{KEITH}$

It's a punctuation mark. We're gonna be moving on to a better place, soon, my friend. I can feel it.

Like uptown?

FUDGE

KEITH

No. Like way further. Like Jamaica.

FUDGE

Now how exactly is it you get to Jamaica from here?

(Keith holds the DOOR OPEN for

Fudge, who EXITS UP)

$\mathrm{KEITH}$

Easy. Just follow the line.

(He follows Fudge, and EXITS.)

SCENE 5

The SET of the show BRITAIN'S

NEXT STAR. 
George and DICK ROWE of DeCCa Records are in MAKE UP CHAIRS preparing to go on camera as guest judges. TWO HAIR AND MAKE UP LADIES get them ready. CREW MEMBERS scurry about with CAMERAS AND LIGHTS.

GEORGE

Perform your magic ladies. It's a good thing these black and white cameras won't show the red in my eyes-

\section{DICK}

Yet another all nighter? Ah, to be young again. You do have a reputation to maintain. Just another day at the office, eh?

GEORGE

Answering the call of duty, sir. Someone has to do it.

DICK

Your lot should be well chuffed. You've paid your dues. I, on the other hand am headed to the polar opposite. I will go down in history as the idiot who turned down the Beatles. Decca Records took a pass on The Fab Four. Our rivals immediately scooped you, of course. I instead recommended David Dunwoody and the Druids.

Who?

GEORGE

\section{DICK}

Exactly. I'm sure I'll be sacked at month's end, out competing for a position at some fledgeling outfit just starting up. From the top of the mountain all the way down to the bottom.

GEORGE

...Well Dick, today is your lucky day. We saw a new band last night. They set the house on fire. They're playing at a club at the Station Hotel. They're called The Rollin' Stones-

(An ASSISTANT DIRECTOR INTERRUPTS)

ASSISTANT DIRECTOR

Gentlemen, this way, please- 
There is a LONGER PAUSE than USUal, as CHEERY THEME MUSIC wells up-

SCENE 6

The set of $A B C^{\prime}$ S SHINDIG!. May 1965. The show is IN PROGRESS. The Rolling Stones are now in full glory. COLORFULLY dressed white teenaged extras surround the band, dancing for THE THREE FLOOR CAMERAS. HOST JIMMY O'NEIL approaches the MINI STAGE.

$\mathrm{O}^{\prime} \mathrm{NEIL}$

America, a big hand for England's latest hit makers- The Rolling Stones!



$\mathrm{O}^{\prime} \mathrm{NEIL}$

The band has made a special request. Brian?

BRIAN

We started because we wanted to play rhythm and blues, and Howlin' Wolf was one of our idols-

$\mathrm{O}^{\prime} \mathrm{NEIL}$

Mick, anything you'd like to add?

$$
\text { (Brian grabs the mic back) }
$$

BRIAN

It's about time we shut up and we put Howlin' Wolf on the stage!

$\mathrm{O}^{\prime} \mathrm{NEIL}$

Ladies and Gentlemen, Charles Burnett! A.K.A. The Howlin' Wolf!

(He ENTERS. IT'S THE SAME ACTOR

from Act 1, Scene 1 . 
He APPROACHES THE MIC, EVERYBODY

SITS AROUND HIM. He has a

HARMONICA. A SPOTLIGHT HITS HIM.)

HOWLIN' WOLF

Before we go any further, I wanna thank these kids. The Rolling Stones, Ladies and Gentlemen. And all the other British kids that are making this Invasion, by breathing new life back into the music us old timers played, and puttin' some that light back on us.

The SURROUNDING LIGHTS HAVE DIMMED. ONLY WOLF is in the NARROWING SPOT.

HOWLIN' WOLF

One of those ole' songs is 'bout a young kid who is forced to make a life choice. He takes the road with music on it. It's called Crossroads, and it goes like this:

(It goes BLACK. The FINAL CURTAIN DROPS . )

\section{THE END}

